Wtodzimierz Cieciura

Uniwersytet Warszawski

\title{
Przyjaźń i interesy w epoce postkolonialnej Narzędzia polityki zagranicznej Chińskiej Republiki Ludowej wobec Afryki
}

Rosnące zaangażowanie gospodarcze i polityczne Chińskiej Republiki Ludowej w Afryce stało się w ostatnich kilkunastu latach jednym z najbardziej kontrowersyjnych tematów współczesnych stosunków międzynarodowych. Stosunki chińsko-afrykańskie są dla wielu zachodnich polityków i badaczy punktem odniesienia w rozważaniach nad chińskimi intencjami i przyszłymi wzorami zachowań politycznych oraz gospodarczych na arenie międzynarodowej. W stosunkowo krótkim czasie Chiny zostały jednym z głównych odbiorców afrykańskich surowców naturalnych i innych towarów koniecznych dla ich dalszego rozwoju gospodarczego. $Z$ drugiej strony, w tym samym czasie ChRL zajęła miejsce czołowego dostawcy produktów przetworzonych, często uznawanych za poślednie gatunkowo, na rynki afrykańskie. Tym zjawiskom gospodarczym towarzyszy wzrost roli politycznej Pekinu na kontynencie, gdzie Chiny zdobywają coraz silniejszą pozycję, rzucając tym samym wyzwanie dotychczasowym głównym aktorom, a przede wszystkim państwom Zachodu. Nie brakuje głosów oskarżających je o bezwzględny wyzysk bogactw naturalnych, a nawet zarzucających ChRL prowadzenie polityki neokolonialnej. O takie praktyki w Afryce oskarżyła Pekin m.in. amerykańska sekretarz stanu Hillary Clinton, mówiąc w 2011 r. w wywiadzie dla zambijskiej telewizji: „W czasach kolonializmu widzieliśmy, że łatwo jest przyjść, zabrać surowce naturalne, spłacić miejscowych przywódców, a potem odejść nie zostawiając za sobą niczego dla ludzi, którzy tu żyją. Nie chcemy nowego kolonializmu w Afryce".

Wcześniej, w 2006 r., w czasie wizyty w Nigerii podobne oskarżenia pod adresem chińskiej polityki kierował brytyjski minister spraw zagranicznych Jack Straw, mówiąc, że postępowanie Chin nie różni się znacząco od praktyk

1 Clinton Chastises China on Internet, African „New Colonialism”, http://www.bloomberg. com/news/2011-06-11/clinton-chastises-china-on-internet-african-new-colonialism.html [dostęp 12.10.2012]. 
brytyjskiego kolonializmu 150 lat wcześniej². Również niektórzy politycy afrykańscy zarzucają Chinom kolonialny wyzysk kontynentu. Jeden z najbardziej antychińskich przywódców w Afryce, lider zambijskiego Frontu Patriotycznego i kandydat w wyborach prezydenckich w 2006 r., Michael Sata z antychińskiej retoryki uczynił jedno z głównych narzędzi swojej walki politycznej, oskarżając Pekin o „bycie nowym kolonizatorem w Afryce”. Choć Sata przegrał wybory, to w stolicy kraju, Lusace i „pasie miedziowym” na północy kraju, gdzie inwestycje chińskie i obecność Chińczyków są najbardziej odczuwalne, wygrał głosowanie 3

Tego rodzaju zarzuty są, oczywiście, stanowczo odrzucane przez stronę chińską, dla której oskarżenie o praktyki neokolonialne jest szczególnie dotkliwe ze względu na retorykę przyjętą w polityce zagranicznej po 1949 r. Podkreśla ona niezmiennie wspólne historyczne doświadczenia Chin i państw trzeciego świata jako ofiar zachodniego imperializmu i kolonializmu. Dzięki stałemu repertuarowi retorycznemu i odwołaniom do „wspólnych doświadczeń ofiar kolonializmu” władze chińskie mogą utrzymywać wśród afrykańskich elit wizerunek Chin jako wiarygodnego i solidnego przyjaciela. W wymiarze wewnętrznym retoryka ta pozwala kultywować popularne w społeczeństwie przekonanie o moralno-etycznej wyższości chińskiej polityki zagranicznej nad praktykami państw zachodnich, co jest szczególnie istotne w obliczu narastających oddolnie tendencji nacjonalistycznych ${ }^{4}$.

Doskonałym przykładem tego rodzaju retoryki może być wypowiedź byłego kierownika departamentu Afryki chińskiego Ministerstwa Spraw Zagranicznych Lu Shaye (ur. 1964) na „forum silnego państwa”, zorganizowanym w styczniu 2012 r. przez dziennik „Renmin Ribao”: „Zastanówmy się, czym jest kolonializm? Oni [Zachód - W.C.] rabowali surowce naturalne drogą zbrojną lub oszustwem, handlowali afrykańską ludnością, okupowali afrykańskie terytoria, niszczyli afrykańską kulturę. Czy tak postępują Chiny? Nie. [...] Chiny pomagają państwom afrykańskim budować drogi, mosty, szpitale, szkoły. Kupują afrykańskie surowce za uczciwe ceny, podnosząc wartość tych surowców i powodując, że Afryka odnosi z nich większe korzyści. Nie ingerujemy w wewnętrzne kwestie polityczne państw afrykańskich, nie zmuszamy państw Afryki do przyjęcia naszej kultury i wartości, lecz prowadzimy z nimi wymianę opartą na zasadach równości i nawzajem się od siebie uczymy"s.

2 G. Mohan, M. Power, New African Choices? The Politics of Chinese Engagement in Africa and the Changing Architecture of International Development, „Review of African Political Economy" 2008, 35, 1, s. 23-42.

3 B. Sautman, Yan Hairong, African Perspectives on China-Africa Links, „China Quarterly” 2009, vol. 199, s. 728-759.

4 J.C. Strauss, The Past in the Present: Historical and Rhetorical Lineages in China's Relations with Africa, „China Quarterly” 2009, vol. 199, s. 777-795.

5 Waijiaobu: Zhongguo zai Feizhou, ,xin zhiminzhuyi” lun meiyou shishi yiju [Ministerstwo Spraw Zagranicznych: koncepcja chińskiego neokolonializmu w Afryce nie ma żadnych rzeczywistych podstaw], http://gb.cri.cn/27824/2012/01/11/2625s3518403.htm [dostęp 12.07.2012]. 
Podobnymi argumentami, lecz podanymi w znacznie mocniejszej formie, posługuje się Li Ruogu, prezes finansującego chińskie inwestycje w Afryce Banku Eksportowo-Importowego (tzw. Exim Bank). Według Li demonizowanie politycznej roli Chin w Afryce wynika z obaw rządów zachodnich o swoją dotychczasową pozycję na kontynencie. Stosunki między ChRL i państwami afrykańskimi, oparte na zasadzie nieingerowania w wewnętrzne sprawy partnerów, oraz bezwarunkowa wymiana handlowa i pomoc udzielana przez Chiny państwom Afryki doprowadziły do „porażki zachodnich koncepcji neoliberalnych w Afryce”. Li twierdzi wprost, że zachodni model rozwojowy przegrywa w Afryce z podejściem chińskim, uznającym ,prawo do rozwoju” za nadrzędne w stosunku do preferowanych przez Zachód zasad demokracji i praw człowieka. Jak ujął to Li, w ocenie chińskiej „[...] »demokracja« i »wolność« nie przystają do Afryki”. Według niego zasada obopólnych korzyści, której hołdują w swoich stosunkach z państwami afrykańskimi Chiny, jest diametralnie odmienna od praktyk państw zachodnich, „wykorzystujących swoją potęgę w polityce międzynarodowej do tworzenia górnolotnych zasad, takich jak »demokracja« $\mathrm{i}$ »wolność« oraz tzw. standardów międzynarodowych itp., które nie licząc się z rozwojem Afryki, utrzymują ją na poziomie dostawcy podstawowych produktów, co nie różni się znacząco od kilkusetletniej praktyki kolonializmu" ". A zatem, według Li Ruogu to Chiny jako pierwsze dają Afryce szansę na wyzwolenie się od dziedzictwa kolonializmu i rozpoczęcie samodzielnego bytu poza zachodnią dominacją.

Znana specjalistka do spraw afrykańskich w Chińskiej Akademii Nauk Społecznych He Wenping różnice w polityce Zachodu i Chin wobec Afryki w bardziej wyważony sposób oddała jako przywiązywanie przez państwa Zachodu „uwagi do programów software, takich jakich jak rozwój zdolności, podczas gdy Chiny przyznały priorytet inwestycjom w bardziej odczuwalne programy typu hardwa$r e$, takie jak budowa dróg, mostów i innej infrastruktury, która może bezpośrednio przysłużyć się Afrykanom"».

Stephanie Rupp, która podjęła się analizy oskarżeń Pekinu o praktyki kolonialne lub neokolonialne ocenia, że żaden z tych zarzutów nie jest trafny. Według niej Chiny wpływają na te cechy systemów politycznych i gospodarczych krajów afrykańskich, które wzmacniają struktury państwowe afrykańskich partnerów, często na niekorzyść zwykłych obywateli tych państw. Ze względu na duże różnice potencjałów Chin i poszczególnych państw afrykańskich stosunki Pekinu z tymi partnerami mogą jednak przypominać zależność z czasów kolonialnych. Rupp zauważa jednak, że zasadnicze różnice pomiędzy polityką chińską wobec

${ }^{6}$ Li Ruogu, Xifang dui Zhong-Fei hezuo de waiqu jiqi zhengwei [Zniekształcanie i fałszowanie współpracy chińsko-afrykańskiej przez Zachód], „Shijie Jingji yu Zhengzhi” [Światowa Gospodarka i Polityka] 2009, no. 4, s. 16-25.

7 Ibidem, s. 24.

${ }^{8}$ He Wenping, Laying Foundation for the Future. Infrastructure Moves Help China Carve an Indelible Niche in Africa, „China Daily European Weekly”, 29.06-5.07.2012, s. 7. 
Afryki a praktykami z okresu europejskiego kolonializmu to przywiązywanie dużej wagi do suwerenności państw kontynentu, kultywowanie dobrych relacji z ich przedstawicielami na forach międzynarodowych oraz zainteresowanie mieszkańcami kontynentu przede wszystkim jako konsumentami, a nie pracownikami. Powyższe argumenty pozwoliły Rupp zdefiniować typ relacji chińsko-afrykańskich jako ,postkolonialną relację współzależności”, choć zaburzoną przez nierównowagę potencjałów obu stron?.

Jakie są jednak faktyczne przyczyny rosnącego zaangażowania Chin w Afryce? Robert I. Rotberg, były profesor Uniwersytetu Harvarda i członek zespołu doradczego ds. Afryki amerykańskiego sekretarza stanu, określa relacje chińsko-afrykańskie mianem „symbiotycznych”, podkreślając, że Chiny i Afryka desperacko się nawzajem potrzebują: „Chiny nie mogą łatwo się rozwijać bez Afryki, a subsaharyjska Afryka [...] nie może egzystować, a obecnie również rozwijać się bez Chin"10. Według Rotberga motywacje Chin są głównie merkantylistyczne - Pekin poszukuje przede wszystkim surowców mineralnych: ropy naftowej, drewna, żelazochromu, kobaltu, platyny, miedzi, diamentów itd. Równocześnie tym materialnym celom polityki afrykańskiej towarzyszą cele ideologiczne - Afryka może dowieść, że chiński model rozwojowy jest możliwy do wyeksportowania, a chińscy stratedzy wierzą, iż lekcje płynące z rozwoju Chin w ostatnich 30 latach mogą być pożyteczne dla Afryki ${ }^{11}$. Autor ten zwraca również uwagę na fakt, że wśród ideologicznych celów afrykańskiej polityki należy umieścić chęć dalszej marginalizacji Tajwanu na arenie międzynarodowej.

Faktycznie, wraz z rosnącym zaangażowaniem ChRL i wzrostem jej pozycji gospodarczej i politycznej liczba państw afrykańskich utrzymujących stosunki dyplomatyczne z Republiką Chińską na Tajwanie spadła do zaledwie czterech w 2012 r. Sam ten fakt oznacza jednak, jak zauważa He Wenping, że czynnik tajwański w afrykańskiej polityce Chin stracił na rzeczywistym znaczeniu. Według He prawdziwymi „siłami napędowymi” afrykańskiej polityki Pekinu są długoterminowe interesy strategiczne i rosnąca pozycja ChRL na arenie międzynarodowej. Chiny, które według He, w odróżnieniu od Zachodu, nie traktują Afryki jako pionka, ale jako pełnoprawnego partnera, potrzebują państw afrykańskich do „przeciwstawiania się hegemonizmowi i polityce siły” Zachodu ${ }^{12}$. Jako dowód skuteczności chińskiej polityki budowania trwałych partnerstw z państwami afrykańskimi He przytacza fakt, że już do 2004 r. państwa afrykańskie, zajmujące 15. z 53 miejsc w komisji praw człowieka ONZ, pomogły zablokować na tym

9 S. Rupp, Africa and China: Engaging Postcolonial Interdependencies, [w:] China into Africa. Trade, Aid and Influence, R.I. Rotberg (ed.), Brookings Institution Press, Washington DC 2008, s. 66.

10 R.I. Rotberg, China's Quest for Resources, Opportunities, and Influence in Africa, [w:] China into Africa. Trade..., s. 1.

11 Ibidem, s. 2.

12 He Wenping, The Balancing Act of China's Africa Policy, „China Security” 2007, vol. 3, no. 3 , s. $23-40$. 
forum jedenaście inicjatyw Stanów Zjednoczonych i innych państw zachodnich zmierzających do potępienia Chin. Według He oznacza to, że Chiny i Afryka zjednoczyły siły w celu przeciwstawienia się zachodnim wysiłkom „narzucenia innym swoich wartości”'13.

Niezależnie od kontrowersji wokół chińskiego zaangażowania w Afryce, czarny kontynent jest obecnie jednym z ważnych obszarów politycznych działań Pekinu. Część badaczy zwraca przy tym uwagę, że nie jest to dla ChRL obszar o znaczeniu priorytetowym, a nasilające się chińskie kontakty z Afryką są jedynie funkcją wzrastającej integracji Chin ze światem i polityki „wyjścia na zewnątrz” (zouchuqu $)^{14}$. Zróżnicowanie kulturowe, geograficzne, polityczne i gospodarcze Afryki, podzielonej między 54 suwerenne państwa, zamieszkanej przez miliard ludzi, stanowiących $15 \%$ populacji globu, spowodowało, że ChRL podjęła szereg kroków zmierzających w stronę większej koherencji swoich stosunków z państwami kontynentu.

\section{Dyplomatyczne narzędzia chińskiej polityki wobec Afryki}

Istnieje kilka ośrodków decyzyjnych formułujących i koordynujących politykę ChRL wobec Afryki. Najważniejszym organem kształtującym i kierującym afrykańską polityką ChRL jest Biuro Dyrekcji Spraw Zagranicznych Komitetu Centralnego Komunistycznej Partii Chin oraz Biuro Spraw Zagranicznych Rady Państwowej ChRL, która jest najwyższym organem władzy wykonawczej w ChRL. W jej skład wchodzą premier, wicepremierzy oraz szefowie poszczególnych ministerstw. Ministerstwo Spraw Zagranicznych, odpowiedzialne za doradzanie przywódcom oraz wdrażanie polityki wobec państw afrykańskich, rozdziela poszczególne zadania swoim departamentom ds. Afryki Subsaharyjskiej oraz Bliskiego Wschodu i Północnej Afryki ${ }^{15}$. Od 1991 r. jako nieformalna tradycja przyjęło się, że minister spraw zagranicznych ChRL pierwszą wizytę w nowym roku odbywa w Afryce ${ }^{16}$. Ministerstwu podlega 49 ambasad na kontynencie afrykańskim, w tym najnowsza w Południowym Sudanie ${ }^{17}$. Pod względem

13 Ibidem, s. 27.

${ }^{14}$ L. Corkin, Redefining Foreign Policy Impulses toward Africa: The Role of the MFA, the MOFCOM and China Exim Bank, ,Journal of Current Chinese Affairs” 2011, vol. 4, s. 62.

15 K. Brown, Zhang Chun, China in Africa - Preparing for the Next Forum for China Africa Cooperation, Chatham House Asia Programme Briefing Note, June 2009, s. 10.

16 D.H. Shinn, China's Growing Role in Africa: Implications for U.S. Policy, Hearing Held by Senate Committee on Foreign Relations Subcommittee on African Affairs Dirksen Senate Office Building, 1.11.2011, http://www.foreign.senate.gov/imo/media/doc/David_Shinn_Testimony.pdf [dostęp 2.01.2013].

17 http://www.fmprc.gov.cn/mfa_chn/wjb_602314/zwjg_603776/zwsg_603778/[dostęp 3.01.2013]. 
liczby ambasad na kontynencie afrykańskim ChRL ustępuje jedynie Stanom Zjednoczonym.

Ministerstwo Handlu koordynuje działania w sferach handlu zagranicznego, inwestycji oraz pomocy. Wielu badaczy wskazuje jednak, że na poziomie ministerialnym to właśnie Ministerstwo Handlu przejęło w kwestiach polityki afrykańskiej inicjatywę. Biura radców handlowych w ambasadach ChRL są niezależne od MSZ i podlegają bezpośrednio ministrowi handlu, który z dużą regularnością odbywa oficjalne wizyty w Afryce (z reguły w zbliżonym czasie do wizyt ministra spraw zagranicznych), w czasie których podpisuje konkretne umowy o współpracy, pożyczkach czy pomocy rozwojowej dla krajów kontynentu i dba o własną sieć dobrych relacji z ich władzami ${ }^{18}$. W przypadku pomocy rozwojowej Wydział Pomocy Zagranicznej Ministerstwa Handlu nie koordynuje swoich działań bezpośrednio z MSZ, czym wywołuje rosnącą irytację tego ostatniego. Lucy Corkin nazywa tę sytuację uzurpacją przez Ministerstwo Handlu tradycyjnych obowiązków MSZ, które zostało zepchnięte do roli organu odpowiadającego jedynie za kwestie dyplomatyczne, podczas gdy to urzędnicy Ministerstwa Handlu wzięli na siebie obowiązki wprowadzania konkretnych rozwiązań politycznych na kontynencie ${ }^{19}$.

Kolejnym ważnym organem rządowym kształtującym politykę wobec Afryki jest Komisja Rady Państwowej ds. Kontroli i Zarządzania Własnością Państwową (Guowuyuan Guoyou Zichan Jiandu Guanli Weiyuanhui, Guoziwei - GZW lub w angielskiej wersji SASAC) o randze równej ministerstwom spraw zagranicznych i handlu ${ }^{20}$. Komisja odpowiada za przedsiębiorstwa będące wyłączną własnością państwa i te, w których państwo posiada pakiety kontrolne, a których wiele działa w Afryce, i do kontroli których posiada tu swoje biura ${ }^{21}$. Ponieważ większość przedsiębiorstw państwowych jest obecnie notowana na chińskich bądź zagranicznych giełdach, interesy Komisji zależą od kursu akcji danego przedsiębiorstwa. Powoduje to, że Komisji zdarza się wymuszać na podległych jej przedsiębiorstwach państwowych działania mające przynieść zysk za wszelką cenę, nawet jeśli szkodzi to wizerunkowi ChRL bądź stoi w niezgodzie z interesami strategicznymi Chin w Afryce ${ }^{22}$. Bank Eksportowo-Importowy (Exim Bank, Zhongguo Jinchukou Yinhang) jest jedynym państwowym bankiem udzielającym pożyczek pomocowych, kredytów i gwarancji ${ }^{23}$.

Wydział Międzynarodowy KPCh odpowiada za współpracę z partiami politycznymi państw afrykańskich, tworząc podstawy dla stosunków dyplomatycznych oraz gospodarczych, organizuje wzajemne wizyty oraz dba, by polityka

\footnotetext{
18 L. Corkin, Redefining Foreign Policy..., s. 67.

19 Ibidem, s. 68.

20 B. Gill, J. Reilly, The Tenuous Hold of China Inc. in Africa, „The Washington Quarterly”,
} 30:3, s. 37-52.

${ }_{21}$ K. Brown, Zhang Chun, China in Africa...

22 B. Gill, J. Reilly, The Tenuous Hold..., s. 42.

${ }_{23}$ K. Brown, Zhang Chun, China in Africa... 
prowadzona wobec krajów regionu pozostawała w zgodzie z chińskimi interesami strategicznymi ${ }^{24}$.

W kwestiach relacji wojskowych z państwami afrykańskimi nadrzędną rolę odgrywa Centralna Komisja Wojskowa KC KPCh, która utrzymuje częste kontakty $\mathrm{z}$ odpowiednimi strukturami państw regionu ${ }^{25}$.

Rządy poszczególnych prowincji, regionów autonomicznych, miast wydzielonych oraz specjalnych regionów administracyjnych Hongkongu i Makao również utrzymują własne kontakty z partnerami afrykańskimi odpowiednimi swojemu szczeblowi.

\section{Forum Współpracy Chiny-Afryka}

Zarówno złożoność, jak i rozproszenie ośrodków decyzyjnych po stronie chińskiej oraz wielkie zróżnicowanie partnerów afrykańskich powodują, że najwyższe władze Chińskiej Republiki Ludowej podejmują wysiłki na rzecz formułowania ogólnej polityki afrykańskiej, choć równocześnie prowadzą pragmatyczne działania dostosowane do warunków poszczególnych krajów. Przejawia się to m.in. w wysiłkach na rzecz instytucjonalizacji współpracy z państwami kontynentu. Najważniejszym narzędziem ChRL w tym aspekcie jest powołane w $2000 \mathrm{r}$. Forum Współpracy Chiny-Afryka (Zhong-Fei Hezuo Luntan - FOCAC), będące według oficjalnych źródeł chińskich ,platformą dialogu i kolektywnej konsultacji, utworzoną przez Chiny i zaprzyjaźnione państwa afrykańskie, oraz mechanizmem współpracy między rozwijającymi się państwami, co wpisuje się we współpracę Południe-Południe"26.

Organizacja ta powstała z obopólnej potrzeby stworzenia platformy konsultacji Chin z państwami kontynentu, a jako pierwsze z oficjalną inicjatywą wyszły niektóre państwa afrykańskie, m.in. Madagaskar, którego minister spraw zagranicznych zaproponował utworzenie forum Chiny-Afryka (na wzór podobnych mechanizmów, takich jak szczyt francusko-afrykański) w czasie swojej wizyty w Chinach w 1999 r. ${ }^{27} \mathrm{~W}$ styczniu tego samego roku podobne sugestie przekazał ówczesnemu wicepremierowi ChRL Li Lanqingowi m.in. egipski dyplomata i zastępca sekretarza generalnego Unii Jedności Afrykańskiej Ahmed Haggag. Li był tym urzędnikiem chińskim, który wyjątkowo dobrze rozumiał potrzebę

${ }^{24}$ Ibidem, s. 10.

25 Ibidem.

${ }^{26}$ Characteristics of FOCAC, http://www.fmprc.gov.cn/zflt/eng/gylt/ltjj/t157576.htm [dostęp 3.12.2012].

${ }^{27}$ Li Anshan, Zhong-Fei hezuo yu Chixu Fazhan. Zhong-Fei Hezuo Luntan de Juese yu Zuoyong [Współpraca chińsko-afrykańska i trwały rozwój. Rola i Działania Forum Współpracy Chiny-Afryka], Raport dla WWF China, 13.07.2012, http://www.wwfchina.org/wwfpress/publication/ shift/chinaafrica2.pdf [dostęp 5.12.2012]. 
lepszej koordynacji afrykańskiej polityki swojego kraju oraz utworzenia organizacji intensyfikującej chińską aktywność w Afryce. W 1995 r. boleśnie przekonał się o kruchości ówczesnej pozycji politycznej ChRL na Czarnym Lądzie, gdy $\mathrm{w}$ drodze powrotnej z oficjalnej wizyty w Senegalu dotarła do niego informacja o zerwaniu przez Dakar stosunków dyplomatycznych z Pekinem i nawiązaniu ich z rządem w Tajpej ${ }^{28}$. O utworzenie multilateralnego mechanizmu dialogu chińsko-afrykańskiego apelowali również liczni dyplomaci afrykańscy, z którymi spotykał się w czasie swojej wizyty na kontynencie chiński minister spraw zagranicznych Tang Jiaxuan ${ }^{29}$. W 1998 r. ambasadorzy Zimbabwe, Kamerunu i Gabonu także sugerowali władzom chińskim podjęcie takiej inicjatywy ${ }^{30}$.

O potrzebie ,poprawy mechanizmów kooperacji i konsultacji między Chinami i Afryką" mówił w czasie swojej wizyty w sześciu państwach afrykańskich w maju 1996 r. prezydent ChRL Jiang Zemin, co prawdopodobnie nadało ton myśleniu o chińskiej polityce w Afryce w kolejnych latach wśród decydentów w Pekinie. Pełna sprzeczności afrykańska polityka ChRL została poddana analizom, w efekcie czego pojawiły się silne głosy o potrzebie stworzenia stałych mechanizmów wymiany z Afryką i sformułowania jasnych założeń ${ }^{31}$. Chińscy urzędnicy i dyplomaci zaangażowani w politykę afrykańską zgłosili liczne propozycje formalizacji kontaktów z kontynentem, jak np. pracujący w Afryce Zachodniej dla Banku Eksportowo-Importowego Zhao Changhui, który w 1997 r. w raporcie zatytułowanym Afrykańska strategia Chin (Zhongguode Feizhou Zhanlüe) zaproponował utworzenie na szczeblu centralnym specjalnej instytucji rządowej zajmującej się kwestiami polityki wobec Afryki i koordynacją działań najważniejszych organów państwowych, takich jak właściwe ministerstwa, na tym polu ${ }^{32}$. Zdecydowanym zwolennikiem instytucjonalizacji stosunków chińsko-afrykańskich $\mathrm{w}$ formie multilateralnego mechanizmu konsultacji był również pełniący wówczas funkcję szefa Departamentu Afryki chińskiego MSZ Liu Guijin - dyplomata z wieloletnim doświadczeniem ambasadorskim, m.in. w Kenii i Zimbabwe. Po wizycie madagaskarskiego ministra w 1999 r. został on poproszony przez ministra Tanga o zorganizowanie wewnątrzministerialnej narady, w wyniku której urzędnicy ministerstwa zdecydowali w głosowaniu o zgłoszeniu sugestii powołania Forum Chiny-Afryka do Rady Państwowej. W toku obustronnych konsultacji między ministerstwem i Radą podjęto ostatecznie decyzję o zaproszeniu partnerów afrykańskich do udziału w tworzeniu Forum. Dwustronną komunikację między ministerstwem i Radą oraz przyjmowanie przez „centrum” sugestii ze strony ekspertów i odpowiednich departamentów w MSZ chiński badacz Li

\footnotetext{
${ }^{28}$ Li Anshan, Zhong-Fei hezuo..., s. 11.

29 Idem, Championing the Right Cause, „China Daily”, 29.06.2012, s. 7.

${ }^{30}$ Idem, Zhong-Fei hezuo..., s. 11.

31 G. Shelton, F. Paruk, The Forum on China-Africa Cooperation. A Strategic Opportunity, Institute for Security Studies 2008, s. 69-70.
}

32 Li Anshan, Zhong-Fei hezuo..., s. 11. 
Anshan uważa za dowód na powrót władz chińskich do tradycji „centralizmu demokratycznego" (minzhu jizhongzhi) i stosowanie przez nie w praktyce zasad „wielopoziomowego systemu podejmowania decyzji strategicznych w polityce zagranicznej”, przyjętych w erze „otwarcia i reform”"33. Kierując się tymi samymi zasadami, Jiang Zemin zwrócił się w październiku 1999 r. do przywódców państw afrykańskich z prośbą o wyrażanie opinii i sugestii w procesie przygotowawczym do powołania Forum. Swoje uwagi zgłosiły m.in. rządy RPA, Gwinei i Kenii.

W pierwszej inauguracyjnej konferencji ministerialnej organizacji, zorganizowanej w październiku 2000 r. w Pekinie, wzięli udział przedstawiciele 80 chińskich ministerstw i 44 afrykańskich państw; jedynie pięć państw kontynentu zaproszonych przez stronę chińską, utrzymujących stosunki dyplomatyczne z rządem na Tajwanie, odmówiło uczestnictwa ${ }^{34}$. Obradowano w czterech odrębnych sesjach tematycznych, poświęconych kwestiom handlu, chińskich reform gospodarczych, zwalczaniu ubóstwa i trwałemu rozwojowi oraz współpracy w dziedzinach edukacji, nauki, technologii i służby zdrowia. Ustalono wówczas również trzyletni plan rozwoju chińsko-afrykańskich stosunków gospodarczych i anulowanie części długów państw Afryki wobec Chin. Strona chińska zadeklarowała ponadto zwiększenie pomocy dla państw kontynentu oraz zapowiedziała zwiększenie zachęt dla chińskich przedsiębiorstw do inwestowania w Afryce ${ }^{35}$.

W przemówieniu otwierającym konferencję Jiang Zemin wezwał do podjęcia wspólnych chińsko-afrykańskich wysiłków na rzecz budowy nowego międzynarodowego porządku gospodarczego i politycznego $0^{36}$. W przyjętej na zakończenie spotkania „deklaracji pekińskiej” uczestnicy zadeklarowali m.in. determinację na rzecz dalszej konsolidacji i rozwoju stosunków chińsko-afrykańskich na wszystkich poziomach i we wszystkich dziedzinach oraz ustanowienie długoterminowego, stabilnego partnerstwa w ramach współpracy Południe-Południe, opartego o wzajemne poszanowanie i obopólne korzyści ${ }^{37}$. W czasie konferencji przyjęto również „Program współpracy Chiny-Afryka w dziedzinach gospodarki i rozwoju społecznego", który zawiera pięć podstawowych zasad stosunków i współpracy Chin i Afryki:

33 Ibidem, s. 22. Zagraniczni badacze wskazują jednak raczej na brak jasnej hierarchii w procesie decyzyjnym w chińskiej polityce zagranicznej, co powoduje, że w sytuacji zachodzenia na siebie kompetencji różnych instytucji o równym statusie decyzje podejmowane są coraz częściej w wyniku wielostronnych konsultacji. Niektórzy określają te zmiany jako przejaw tendencji do „,demokracji wewnątrzpartyjnej”. Zob. L. Corkin, Redefining Foreign Policy..., s. 65-66.

34 M. Meidan, China's Africa Policy: Business Now, Politics Later, „Asian Perspective” 2006, vol. 30 , no. 4 , s. 76 .

35 D. Cissé, FOCAC: Trade, Investments and Ad in China-Africa Relations, Stellenbosch University Center for Chinese Studies, Policy Briefing, May 2012.

36 G. Shelton, F. Paruk, The Forum on China-Africa Cooperation..., s. 70.

${ }_{37}$ Beijing Declaration of the Forum on China-Africa Cooperation, http://www.focac.org/eng/ 1tda/dyjbzjhy/DOC12009/t606796.htm [dostęp 12.12.2012]. 
1. Równości i wzajemnych korzyści;

2. Różnorodności „form i zawartości” (w wersji chińskiej xingshi yu neirong, tj. poszanowania dla odrębności systemowych i politycznych);

3. Nacisku na efekty praktyczne;

4. Dążenia do wspólnego postępu;

5. Przyjaznego rozwiązywania różnic ${ }^{38}$.

Po pierwszej konferencji FOCAC władze chińskie powołały instytucje mające nadać tej organizacji dynamiki i zapewnić jej skuteczne funkcjonowanie. W $2001 \mathrm{r}$. powołano Komitet ds. Realizacji Postanowień (tzw. Follow-up Actions Committee, chiń. Houxu Xingdong Weiyuanhui), w którego pracach uczestniczą przedstawiciele 27 ministerstw i innych organów państwowych zaangażowanych w działalność Forum. Wśród nich centralną rolę odgrywają ministerstwa spraw zagranicznych, finansów i handlu ${ }^{39}$. Pozostałe organy to nie tylko ministerstwa, ale też np. Ludowy Bank Chin, Bank Eksportowo-Importowy, Wydział Kontaktów z Zagranicą KC KPCh oraz Liga Młodzieży Komunistycznej ${ }^{40}$. Ze względu na specyfikę systemu politycznego w ChRL można przypuszczać, że te instytucje partyjne mają niepośledni wpływ na funkcjonowanie mechanizmów decyzyjnych po stronie chińskiej Forum. Wydział Kontaktów z Zagranicą KC KPCh aktywnie zajmuje się m.in. budowaniem i wzmacnianiem relacji między KPCh i partiami rządzącymi w państwach afrykańskich, a jego przewodniczący Wang Jiarui jest ważną postacią w kręgach odpowiedzialnych za kształtowanie polityki zagranicznej ChRL ${ }^{41}$.

Codziennymi pracami Komitetu ds. Realizacji Postanowień kieruje jego Sekretariat, umiejscowiony przy Departamencie Afryki MSZ, a w jego skład wchodzą przedstawiciele tego departamentu, Departamentu Azji i Afryki MSZ (odpowiedzialnego m.in. za sprawy Afryki Północnej), Departamentu Azji Zachodniej i Afryki Ministerstwa Handlu oraz Departamentu Politycznego Ministerstwa Finansów. Sekretariat koordynuje działania organów rządowych ChRL odpowiedzialnych za wdrażanie konkretnych postanowień szczytów organizacji. $\mathrm{Na}$ jego czele stoi szef Departamentu Afryki MSZ - funkcję tę pełni obecnie Lu Shaye (ur. 1964), były ambasador w Senegalu. W ocenie specjalistów Sekretariat dobrze spełnia się $\mathrm{w}$ funkcji instytucji odpowiedzialnej za realizację postanowień szczytów FOCAC oraz skutecznie organizuje i koordynuje spotkania afrykańskich ambasadorów w Pekinie ${ }^{42}$.

38 Programme for China-Africa Cooperation in Economic and Social Development, http:// www.focac.org/eng/ltda/dyjbzjhy/DOC12009/t606797.htm [dostęp 12.12.2012]; Wersja chińska: http://www.focac.org/chn/ltda/dyjbzjhy/hywj12009/t155561 [dostęp 12.12.2012].

39 Li Anshan, Zhong-Fei hezuo..., s. 13.

40 Pełna lista instytucji partycypujących w pracach komitetu: http://www.focac.org/eng/hxxd/ hxwyh/t157590.htm [dostęp 13.12.2012].

${ }^{41}$ L. Corkin, Redefining Foreign Policy..., s. 65.

42 Evaluating China's FOCAC Commitments to Africa and Mapping the Way Ahead, A report by the Stellenbosch University Centre for Chinese Studies Prepared for the Rockefeller Foundation, January 2010, s. 182. 
W dotychczasowej historii FOCAC odbyło się pięć konferencji ministerialnych:

- Druga konferencja ministerialna FOCAC, w dniach 15-16 grudnia 2003 r. w Addis Abebie, w której wzięło udział ponad 70 ministrów ChRL i 44 krajów afrykańskich oraz sześciu prezydentów państw kontynentu, trzech premierów i przewodniczący Komisji Unii Afrykańskiej Alpha Oumar Konaré. Najwyższym przedstawicielem strony chińskiej był premier Wen Jiabao ${ }^{43}$. W czasie wystąpienia otwierającego obrady premier Wen w czterech punktach wyłożył zasady, według których ChRL miała budować swoje stosunki z państwami Afryki: po pierwsze, rozwijać tradycyjną przyjaźń chińsko-afrykańską poprzez wzajemną pomoc; po drugie, wspierać demokratyzację stosunków międzynarodowych poprzez mechanizmy wzajemnych konsultacji; po trzecie, wspólnie podejmować wyzwania globalizacji poprzez koordynację postępowania; po czwarte, wzmocnić współpracę w celu zapoczątkowania nowego rozdziału w historii przyjaznych stosunków chińsko-afrykańskich ${ }^{44}$. Na zakończenie konferencji przyjęto „plan działań z Addis Abeby", ustalający zadania organizacji na lata 2004-2006 i konkretyzujący zakres jej działań w stosunku do bardziej ogólnych ustaleń z Pekinu sprzed trzech lat. W planie tym strona chińska ponowiła zapewnienia o swoim oddaniu sprawie politycznego dialogu i wymiany opinii na wysokim szczeblu, a także powtórzyła obietnice zaangażowania się w wojskowe misje stabilizacyjne na kontynencie oraz w kwestie bezpieczeństwa w kilku obszarach, m.in. przemytu narkotyków, nielegalnej imigracji oraz zwalczania terroryzmu ${ }^{45}$. W czasie szczytu przywódcy chińscy zadeklarowali chęć otworzenia rynku chińskiego dla afrykańskich eksporterów i wprowadzenia polityki zwolnienia z cła dla niektórych afrykańskich towarów ${ }^{46}$.

- Trzecia konferencja ministerialna FOCAC w listopadzie 2006 r., której towarzyszył szczyt Sino-Afrykański, największe wydarzenie dyplomatyczne w historii stosunków chińsko-afrykańskich. Wzięło w nim udział 41 głów państw afrykańskich oraz przywódcy wysokiego szczebla z 48 spośród 53 państw Afryki. Skala szczytu pekińskiego spowodowała, że wydarzenie to postrzegane jest jako moment przełomowy we współczesnych stosunkach chińsko-afrykańskich ${ }^{47}$. Szczyt zapoczątkował również bezprecedensowe zainteresowanie świata problemem stosunków ChRL i Afryki, wpływając na ogromny wzrost liczby opracowań i projektów badawczych podejmujących ten temat.

43 The Second Ministerial Conference of FOCAC, http://www.focac.org/eng/ltda/dejbzjhy/ CI22009/t157581.htm [dostęp 12.12.2012].

${ }_{44}$ Four-Point Proposal of the Chinese Side, http://www.focac.org/eng/ltda/dejbzjhy/CI22009/ t157583.htm [dostęp 12.12.2012].

45 Zob. Zhong-Fei Hezuo Luntan. Yadisi Yabeiba Xingdong Jihua [FOCAC. Plan działań z Addis Abeby], http://www.focac.org/chn/ltda/dejbzjhy/hywj22009/ [dostęp 14.12.2012].

46 D. Cissé, FOCAC: Trade, Investments...

47 Ibidem. 
W czasie szczytu pekińskiego do „deklaracji pekińskiej” z 2000 r. i „planu działań z Addis Abeby" włączono kolejne zobowiązania strony chińskiej wobec jej afrykańskich partnerów. Zostały one włączone do „pekińskiego planu działań FOCAC" i obejmowały m.in. podwojenie pomocy rozwojowej do 2009 r., ustanowienie Chińsko-Afrykańskiego Funduszu Rozwojowego o wartości 5 mld USD (Zhong-Fei Fazhan Jijin), powołanego do życia w 2007 r., zwolnienie z ceł 440 produktów afrykańskich, szkolenie 150 tys. afrykańskich fachowców w Chinach, stworzenie 10 rolniczych centrów pokazowych w Afryce, budowę 30 szpitali oraz 100 szkół na terenach wiejskich, donację 37,5 mln USD na program zwalczania malarii, wysłanie 100 specjalistów ds. rolnictwa, podwojenie liczby stypendiów dla studentów afrykańskich do 4000 w 2009 r. oraz przeznaczenie 3 mld USD w kredytach preferencyjnych oraz 2 mld USD w formie konsumpcyjnych pożyczek importowych ${ }^{48}$.

Pekiński szczyt stanowił kulminację „,roku Afryki” w chińskiej polityce zagranicznej, ogłoszonego z okazji 50-lecia nawiązania przez ChRL stosunków dyplomatycznych z pierwszym państwem afrykańskim - Egiptem. Rok 2006 rozpoczął się od wizyty ministra spraw zagranicznych Li Zhaoxinga w sześciu krajach kontynentu. Wizytę w trzech krajach Afryki złożył w kwietniu Hu Jintao, a w czerwcu aż siedem krajów odwiedził premier Wen Jiabao. W styczniu 2006 r. Ministerstwo Spraw Zagranicznych ChRL opublikowało specjalny dokument, stanowiący niejako ogólną deklarację celów i wartości, którymi kierują się w swojej polityce wobec kontynentu Chiny. „Afrykańska Polityka Chin” (Zhongguo Feizhou Zhengce Wenjian) była zaledwie drugim tego typu opracowaniem po dokumencie dotyczącym polityki europejskiej z 2003 r..$^{49}$ i zawierała określenie relacji chińsko-afrykańskich jako „partnerstwa strategicznego”. Dokument definiuje założenia afrykańskiej polityki ChRL w sześciu podrozdziałach. Pozytywnie oceniając przyszłość stosunków chińsko-afrykańskich, w „Afrykańskiej Polityce Chin" stwierdza się, że relacje powinny być oparte na zasadach „równości, wzajemności, obustronnych zysków, solidarności i wspólnego rozwoju" ${ }^{50}$. W podpunkcie czwartym wskazano sześć obszarów, w których relacje chińsko-afrykańskie powinny ulec wzmocnieniu: wizyty na wysokim szczeblu, wymiany pomiędzy organami ustawodawczymi, wymiany pomiędzy partiami politycznymi, ustanowienie mechanizmów konsultacji międzyrządowych (takich jak: komisje międzynarodowe, konsultacje polityczne między ministrami spraw

48 J. Jansson, The Forum on China-Africa Cooperation (FOCAC), A briefing paper by the Centre for Chinese Studies Prepared for World Wide Fund for Nature (WWF). Centre for Chinese Studies, University of Stellenbosch, August 2009. Pełen tekst ,pekińskiego planu działań FOCAC": http://www.fmprc.gov.cn/zflt/eng/zyzl/hywj/t280369.htm [dostęp 13.12.2012].

49 Pełny angielski tekst dokumentu dotyczącego polityki afrykańskiej: http://www.fmprc.gov. cn/eng/zxxx/t230615.htm [dostęp 23.08.2012]. W 2008 r. MSZ ChRL wydało kolejny dokument tego typu, dotyczący polityki wobec Ameryki Łacińskiej.

50 China's African Policy... 
zagranicznych itp.), współpraca na forum międzynarodowym (m.in. w ONZ) oraz wymiany wizyt pomiędzy władzami regionalnymi ${ }^{51}$. Większość z wymienionych rozwiązań była powszechnie stosowana w afrykańskiej polityce ChRL już wcześniej, ale nacisk na współpracę między partiami i władzami regionalnymi był elementem nowym. Szczególny nacisk na te kwestie wskazywał, że Chiny pragną poszerzenia i zintensyfikowania politycznych relacji z państwami Afryki i dążą do zbudowania mechanizmów współpracy będących solidną podstawą dla szerokiej interakcji na wszystkich szczeblach ${ }^{52}$.

W dokumencie znalazły się również deklaracje woli strony chińskiej zacieśniania współpracy z afrykańskimi organizacjami międzynarodowymi, tj. Unią Afrykańską i Nowym Partnerstwem dla Rozwoju Afryki (NEPAD), oraz wsparcia ich wysiłków rozwoju Afryki. „Afrykańska Polityka Chin” przedstawia zatem szeroką gamę możliwych płaszczyzn współpracy sino-afrykańskiej i stanowi równocześnie zaproszenie dla strony afrykańskiej do efektywnego wykorzystania i zaangażowania się w relacje z ChRL ${ }^{53}$. Wskazanie wśród partnerów afrykańskich NEPAD, organizacji, która deklaruje chęć promocji zasad dobrego rządu i praw człowieka, jest zapewne sygnałem dla krytyków afrykańskiej polityki Chin zarzucających Pekinowi postępowanie całkowicie nieliczące się z tymi kwestiami.

- Czwarta konferencja ministerialna FOCAC odbyła się w Szarm El-Szejk w dniach 8-9 listopada 2009 r., udział w niej wzięli przedstawiciele 49 państw afrykańskich. Zakończyła się ona przyjęciem kolejnego planu działań, w którym powtórzono wiele wcześniejszych zapisów o współpracy na szczeblach politycznym, gospodarczym, edukacyjnym itp. Ponownie podkreślono rolę organizacji międzynarodowych w kształtowaniu współczesnych stosunków międzynarodowych i przekonanie obu stron o konieczności zwiększenia międzynarodowej roli państw ,globalnego Południa" ${ }^{54}$. W planie działań z Szarm El-Szejk po raz pierwszy obie strony odniosły się do kwestii wspólnych działań w rozwiązywaniu problemów związanych ze zmianami klimatycznymi. Choć kwestia ta pojawiła się już w dokumencie „Afrykańska Polityka Chin” z 2006 r., nie znalazła się wówczas w „pekińskim planie działań”. Dopiero w Szarm El-Szejk Chiny i państwa Afryki zadeklarowały, że kwestia zmian klimatycznych powinna być rozwiązywana zgodnie z duchem Ramowej Konwencji ONZ ws. Zmian Klimatu i Protokołu z Kioto. W planie działań z Szarm El-Szejk ChRL zadeklarowała swoje poparcie dla starań państw afrykańskich na rzecz wzmocnienia ich potencjału w zwalczaniu zmian klimatycznych, przy równoczesnym zastrzeżeniu, że nie mogą one odbywać się kosztem rozwoju afrykańskich gospodarek. Strona

51 Ibidem, cz. IV.

52 G. Shelton, F. Paruk, The Forum on China-Africa Cooperation..., s. 112.

53 Ibidem.

54 Forum on China-Africa Cooperation Sharm El Sheikh Action Plan (2010-2012), http:// www.focac.org/eng/dsjbzjhy/hywj/t626387.htm [dostęp 12.12.2012]. 
chińska wyraziła zrozumienie dla faktu szczególnego zagrożenia ze strony zmian klimatycznych dla małych państw wyspiarskich oraz tych położonych w dorzeczach wielkich rzek. Chiny zaznaczyły również, że afrykańskie wysiłki w sferze przeciwdziałania zmianom klimatycznym powinny zostać wsparte przez transfer środków i finansów z krajów rozwiniętych, deklarując równocześnie, że same są gotowe wesprzeć partnerów z Afryki w ich działaniach ${ }^{55}$.

- Piąta konferencja ministerialna FOCAC odbyła się w dniach 19-20 lipca 2012 r. w Pekinie, a udział w niej wzięli przedstawiciele 50 państw afrykańskich, w tym sześciu prezydentów (RPA, Beninu, Gwinei Równikowej, Dżibuti, Nigru, Wybrzeża Kości Słoniowej), dwóch premierów (Kenii i Wysp Zielonego Przylądka) oraz specjalny wysłannik prezydenta Egiptu. Prezydent Beninu Boni Yayi występował równocześnie w funkcji rotacyjnego przewodniczącego Unii Afrykańskiej ${ }^{56}$. Zgodnie z deklaracją z dokumentu „Afrykańska Polityka Chin” o zacieśnianiu więzów współpracy z tą organizacją Chiny poświęcają jej obecnie szczególnie dużo uwagi. Symbolem tego może być sfinansowanie i wybudowanie przez ChRL nowej siedziby Unii w Addis Abebie, wartej $200 \mathrm{mln}$ USD, otwartej W styczniu 2012 r. $^{57}$

Szczyt pekiński zakończył się przyjęciem kolejnej „deklaracji pekińskiej”, podkreślającej wagę stosunków chińsko-afrykańskich jako ,partnerstwa strategicznego" i ich zasadniczego znaczenia w walce z kryzysem finansowym oraz budowie nowego, bardziej zbilansowanego i wielobiegunowego porządku światowego. Deklaracja zawierała ponadto poparcie strony chińskiej dla afrykańskich starań na rzecz uzyskania większego wsparcia ze strony wspólnoty międzynarodowej w celu osiągnięcia założeń Milenijnego Planu Rozwojowego ONZ ${ }^{58}$.

FOCAC jest dla ChRL długoterminowym procesem, przez który Chiny i Afryka osiągną liczne korzyści. Dowodem zainteresowania Chin obecnością w FOCAC jest duża liczba instytucji rządowych zaangażowanych $w$ jego pracę. ChRL z entuzjazmem traktuje FOCAC i dąży do jego sukcesu, a pekiński Sekretariat jest do tego celu dobrze przygotowany. Brak afrykańskiego odpowiednika Sekretariatu po stronie chińskiej powoduje, że Afryka nie ma skutecznego mechanizmu realizacji postanowień ogólnych FOCAC i nie może stworzyć efektywnej relacji z Chinami w ramach FOCAC ${ }^{59}$.

55 Ibidem, pkt 3.5 .

${ }_{56}$ Beijing Declaration of the Fifth Ministerial Conference of the Forum on China-Africa Cooperation. http://www.focac.org/eng/ltda/dwjbzjjhys/hywj/t954245.htm [dostęp 12.01.2013].

57 W. Wallis, China Puts Space-Age Seal on African Role, „Financial Times”, 13.01.2012. Chiny wyasygnowały również $94 \mathrm{mln}$ USD na utrzymanie i pracę chińskiej obsługi siedziby UA w najbliższych latach.

58 Ibidem.

59 Evaluating China's FOCAC Commitments to Africa..., s. 183. 


\section{Specjalny wysłannik rządu ChRL ds. afrykańskich}

Oprócz wysiłków na rzecz stworzenia platformy stosunków multilateralnych, jaką jest FOCAC, ChRL podejmuje również jednostronne inicjatywy w sferze stosunków z regionem Afryki. Można tu wymienić m.in. ustanowienie w maju 2007 r. funkcji specjalnego wysłannika ds. afrykańskich rządu chińskiego (Zhongguo zhengfu Feizhou shiwu tebie daibiao) w randze ambasadora, którego zadaniem jest „praca na rzecz wzmacniania współpracy chińsko-afrykańskiej, zacieśnianie kontaktów z organizacjami z regionu Afryki oraz wspieranie rozwoju stosunków chińsko-afrykańskich" ${ }^{60}$. Jako pierwszy na stanowisko to został powołany Liu Guijin - wcześniej sprawujący funkcję wysłannika rządu ChRL ds. Darfuru - i w początkowym okresie jego nowe obowiązki dotyczyły przede wszystkim tego problemu. Decyzja o stworzeniu tej funkcji była również jednym z elementów aktywizacji chińskiej polityki wobec Afryki po „szczycie pekińskim” i miała według zapewnień MSZ stanowić przejaw poważnego traktowania wcześniejszych deklaracji o woli zacieśnienia stosunków i budowania wzajemnego zaufania ${ }^{61}$.

W czasie pełnienia swoich obowiązków specjalnego wysłannika Liu Guijin co najmniej dwudziestokrotnie odbył oficjalne wizyty w państwach afrykańskich, spotykając się z przedstawicielami najwyższych miejscowych władz ${ }^{62}$. Jako jeden z pierwszych przedstawicieli władz chińskich odwiedził $\mathrm{w}$ grudniu $2011 \mathrm{r}$. nowo powstałe państwo Sudanu Południowego ${ }^{63}$. Do jego obowiązków należały również regularne spotkania $\mathrm{z}$ afrykańskimi ambasadorami w Pekinie oraz z odwiedzającymi Chiny gośćmi z Afryki, a także uczestnictwo w międzynarodowych konferencjach poświęconych problemom Afryki i jej poszczególnych państw (m.in. konferencja dotycząca problemu Somalii, trójstronna konferencja UE-Chiny-Afryka w sierpniu 2008 r. itp.). Jako „twarz” afrykańskiej polityki ChRL Liu odbywał również briefingi z zagranicznymi dziennikarzami, przedstawiając im oficjalne rządowe informacje dotyczące działań Chin na kontynencie ${ }^{64}$.

${ }^{60}$ Zhongguo Zhengfu sheli Feizhou Shiwu Tebie Daibiao 10.05.2007 [Rząd chiński utworzył funkcję Specjalnego Wysłannika ds. Afrykańskich], http://www.fmprc.gov.cn/mfa_chn/ zyxw_602251/t317749.shtml [dostęp 11.12.2012].

${ }^{61}$ Ibidem.

62 Prawdopodobnie niepełny spis tych wizyt można znaleźć na stronie MSZ: http://www.fmprc.gov.cn/wjb/search_new.jsp?page=1\&searchword=\%E4\%B8\%AD $\%$ E5 $\% 9 \mathrm{~B} \% \mathrm{BD} \% \mathrm{E} 6 \% 94 \% \mathrm{~B}-$ F\%E5\%BA\%9C\%E9\%9D\%9E\%E6\%B4\%B2\%E4\%BA\%8B\%E5\%8A\%A1\%E7\%89\%B9\%Е5 $\% 88 \% \mathrm{AB} \% \mathrm{E} 4 \% \mathrm{BB} \% \mathrm{~A} 3 \% \mathrm{E} 8 \% \mathrm{~A} 1 \% \mathrm{~A} 8 \&$ channelid=75004\&prepage=50\&searchChnl= $\quad$ [dostęp 23.01.2013].

${ }^{63}$ Zhongguo Zhengfu Feizhou Shiwu Tebie Daibiao Liu Guijing fangwen Nan Sudan [Specjalny wysłannik rządu chińskiego ds. afrykańskich odwiedził Południowy Sudan], http://www.fmprc. gov.cn/mfa_chn/wjdt_611265/wjbxw_611271/t885504.shtml [dostęp 23.01.2013].

${ }^{64} \mathrm{~W}$ kontekście specyficznych doświadczeń historycznych Chin na kontynencie afrykańskim szczególnie ciekawy przebieg mogły mieć konsultacje przeprowadzone przez Liu z szefem 
W lutym 2012 r. na stanowisko specjalnego wysłannika mianowano innego doświadczonego dyplomatę, Zhong Jianhua, byłego ambasadora w RPA, który kontynuuje pracę Liu, podróżując do Afryki i spotykając się z miejscowymi przywódcami. Ten szczególny nacisk na pielęgnowanie osobistych i częstych kontaktów z liderami afrykańskimi jest jedną z cech charakterystycznych chińskiej polityki praktycznej na kontynencie. W połączeniu z bardzo częstymi wizytami najwyższych przywódców ChRL - sekretarza generalnego KPCh, przewodniczącego rady państwowej i wyższych członków kierownictwa partii ten aspekt polityki afrykańskiej ChRL jest szczególnie mocno podkreślany jako efektywne narzędzie tworzenia specyficznych więzi. Odbiega to od praktyki krajów zachodnich, które nie przywiązują takiej wagi do kontaktów osobistych. Zauważył to m.in. David H. Shinn w swoim raporcie do Kongresu USA, podkreślając, że na tym polu Stany Zjednoczone nie mogą pochwalić się tak szczególnymi relacjami z przywódcami afrykańskimi ${ }^{65}$.

\section{Gospodarcze narzędzia polityki Chińskiej Republiki Ludowej wobec Afryki}

Współczesne stosunki chińsko-afrykańskie często postrzega się jako skoncentrowane przede wszystkim na kwestiach gospodarczych. Potrzeba zapewnienia sobie źródła surowców i zdobycia nowych rynków dla własnego eksportu przez wielu obserwatorów jest uważana za podstawową „siłę napędową" rosnącego chińskiego zaangażowania na kontynencie, dominującą nad chęcią rozszerzenia wpływów politycznych czy eksportu chińskiego modelu rozwojowego ${ }^{66}$. Wspomniane wyżej wyforsowanie się przez Ministerstwo Handlu na pierwsze miejsce wśród chińskich agencji rządowych odpowiedzialnych za politykę afrykańską również wskazuje na dominację motywacji ekonomicznych.

Choć chińskie zainteresowanie Afryką faktycznie w dużej mierze koncentruje się na kwestiach surowcowych - w 2010 r. ok. 70\% afrykańskiego eksportu do Chin pochodziło $\mathrm{z}$ czterech bogatych $\mathrm{w}$ surowce krajów kontynentu ${ }^{67}$ - to chińsko-afrykańskie stosunki gospodarcze są dalece bardziej złożone, dotyczą wielu

departamentu Afryki MSZ Kuby w maju 2010 r. w Hawanie. Interesy obu krajów zderzyły się wcześniej w dramatycznych okolicznościach w Afryce w czasie wojny domowej w Angoli i konfliktu somalijsko-etiopskiego w latach 70. XX w. Zhongguo tong Guba Juxing Feizhou shiwu cuoshang [Chiny i Kuba odbyły konsultacje w sprawach Afryki], http://www.fmprc.gov.cn/mfa_chn/ wjdt_611265/sjxw_611273/t693898.shtml [dostęp 20.01.2013].

65 D.H. Shinn, China's Growing Role in Africa...

${ }_{66}$ M. Meidan, China's Africa Policy..., s. 92.

${ }^{67}$ Czyli Angoli, Sudanu, DR Kongo i RPA. R. Schiere, P. Walkenhorst, Introduction: China's Increasing Engagement in Africa: Towards Stronger Trade, Investment and Development Cooperation, „African Development Review” 2010, vol. 22, no. S1, s. 559. 
sfer i odbywają się na wielu różnych poziomach. Również uczestniczący w nich i wpływający na kształt tych stosunków przedstawiciele strony chińskiej są zróżnicowani i niejednorodni, co powoduje rosnącą trudność efektywnego zarządzania polityką wobec Afryki przez rząd w Pekinie. Najważniejszym uczestnikiem procesu tworzenia polityki ChRL wobec Afryki jest rząd centralny oraz rządy prowincjonalne, a czasem również lokalne, zatrudnieni w nich urzędnicy oraz należące do tych władz i kontrolowane przez nie przedsiębiorstwa państwowe ${ }^{68}$. Drugim czynnikiem kształtującym afrykańską politykę ChRL są prywatne przedsiębiorstwa i ich przedstawiciele w Afryce. Prywatne chińskie przedsiębiorstwa, zachęcone promowaną przez rząd strategią „wyjścia na zewnątrz” (zouchuqu zhanlüe), zaangażowały się biznesowo w Afryce w nadziei zdobycia nowych rynków zbytu dla swoich produktów. Trzecim chińskim uczestnikiem procesu kształtowania stosunków Chin i Afryki są indywidualni chińscy obywatele, zarówno wpływowi pośrednicy handlowi, jak i rosnąca grupa chińskich pracowników w Afryce ${ }^{69}$. Przy takim zwielokrotnieniu uczestników polityki wobec kontynentu afrykańskiego efektywne zarządzanie procesami decyzyjnymi staje się coraz trudniejsze. Konieczność koordynacji działań tych zróżnicowanych aktorów była jedną z przyczyn, dla których rząd centralny zdecydował się powołać Forum Współpracy Chiny-Afryka ${ }^{70}$.

W dokumencie z 2006 r. „Chińska Polityka wobec Afryki” rząd chiński zadeklarował chęć ułatwienia dostępu dla afrykańskich towarów do chińskiego rynku oraz spełnienia swojej obietnicy objęcia części towarów z najmniej rozwiniętych krajów Afryki programem zwolnienia $z$ ceł importowych ${ }^{71}$. Władze ChRL równocześnie wyraziły w nim chęć rozszerzenia i zbalansowania wymiany handlowej z państwami kontynentu. Według tej samej deklaracji wszelkie dysputy handlowe pomiędzy stronami mają być rozwiązywane w drodze przyjaznych negocjacji, w poszanowaniu obustronnych uwarunkowań. Rząd ChRL zobowiązał się też do wsparcia wysiłków przedsiębiorców obu stron w celu powołania Chińsko-Afrykańskiej Izby Handlowej. Co więcej, zadeklarowano także, że „gdy pojawią się sprzyjające okoliczności, Chiny będą skłonne wynegocjować umowę o wolnym handlu z państwami afrykańskimi i afrykańskimi organizacjami regionalnymi" 72 .

Zgodnie z obietnicą z 4 listopada 2006 r., złożoną w czasie pekińskiego szczytu FOCAC, premier Wen Jiabao ogłosił powstanie Chińsko-Afrykańskiej Połączonej Izby Gospodarczo-Przemysłowej (Zhongguo Feizhou Lianhe Gongshang Hui). Izba została powołana wspólnie przez chińską Radę Promocji

\footnotetext{
${ }_{68}$ K. Brown, Zhang Chun, China in Africa..., s. 9.

69 Ibidem.

70 Ibidem.

${ }^{71}$ China's African Policy, http://www.fmprc.gov.cn/eng/zxxx/t230615.htm [dostęp 20.07.2012].

72 Ibidem.
} 
Handlu Zagranicznego (CCPIT), podległą radzie państwowej ChRL, oraz Afrykańskie Stowarzyszenie Izb Handlowych, Przemysłowych, Rolnych i Zawodowych (UACCIAP). Jest ona instytucją ściśle kontrolowaną przez władze chińskie za pośrednictwem CCPIT, która w 2009 r. utworzyła Sekretariat organizacji, umiejscowiony w tzw. biurowcu dyplomatycznym w pekińskiej dzielnicy Jianguomen, na czele którego postawiono urzędników CCPIT i Ministerstwa Handlu ${ }^{73}$. Izba deklaruje, że w swojej działalności kieruje się zasadami non-profit i pełni funkcje usługowe dla biznesu. Jednak według danych podawanych przez Izbę na jej stronie internetowej większość jej członków stanowią duże przedsiębiorstwa państwowe, takie jak m.in.: China Development Bank, China Nonferrous Mining Group, China Complete Plant Import\&Export Corporation itp. ${ }^{74}$

Władzom ChRL wciąż nie udało się natomiast podpisać porozumienia o wolnym handlu z żadnym państwem afrykańskim lub organizacją regionalną. Już od 2004 r., kiedy RPA uznała Chiny za gospodarkę rynkową, prowadzone są jedynie rozmowy z Unią Celną Afryki Południowej (SACU), w skład której wchodzą: RPA, Botswana, Namibia, Lesotho i Suazi ${ }^{75}$ (co ciekawe, ten ostatni kraj jest jednym z nielicznych państw afrykańskich, które konsekwentnie utrzymuje stosunki dyplomatyczne z Republiką Chińską na Tajwanie). Brak porozumienia wynika m.in. z obaw RPA przed podpisaniem tego typu umowy z ChRL, która, według ministra handlu i przemysłu RPA Roba Daviesa, dysponuje zbyt wielką przewagą gospodarczą nad Pretorią ${ }^{76}$.

\section{Handel}

Badacze, tacy jak Judith van de Looy, wskazują, że dla ChRL rozwój stosunków gospodarczych z Afryką jest istotny z trzech powodów: zapotrzebowania Chin na surowce naturalne, przede wszystkim ropę naftową, atrakcyjności Afryki jako rynku zbytu dla chińskich towarów oraz ze względu na możliwości inwestycyjne dla chińskich przedsiębiorstw ${ }^{77}$. Wśród importowanych przez ChRL towarów afrykańskich dominują kopaliny, takie jak ropa naftowa, oraz inne surowce, podczas gdy wśród importu chińskiego do Afryki przeważają towary przetworzone, jak produkty przemysłowe, urządzenia elektryczne, tekstylia oraz $\mathrm{AGD}^{78}$. Wśród 10 największych partnerów handlowych Chin na kontynencie afrykańskim

${ }^{73} \mathrm{http}: / /$ www.china-africajcci.org/english/about_us.asp [dostęp 28.07.2012].

74 Ibidem.

75 China Free Trade Agreements Network, http://fta.mofcom.gov.cn/topic/ensacu.shtml [dostęp 1.08.2012].

76 South Africa: Free-Trade Agreement with China Not on Cards, „All Africa”, 7.7.2010, http://allafrica.com/stories/201007070034.html [dostęp 1.08.2012].

77 J. van de Looy, Africa and China: a Strategic Partnership?, ASC Working Paper 67/2006, African Studies Center, Leiden, s. 14.

78 Ibidem. 
sześć krajów jest eksporterami ropy naftowej, trzy posiadają zdywersyfikowane gospodarki, a jeden jest krajem o gospodarce typowo rolnej ${ }^{79}$. Choć surowce mineralne stanowią większość chińskiego importu z Afryki, Chiny wdrażają coraz bardziej zróżnicowane strategie handlowe w stosunkach z państwami kontynentu. Wynika to z rosnącego zapotrzebowania rynku krajowego również na nietradycyjne, przetworzone produkty afrykańskie ${ }^{80}$.

W 2010 r. Chińska Republika Ludowa stała się największym partnerem handlowym Afryki, wyprzedzając Stany Zjednoczone ${ }^{81}$. Według danych przytoczonych przez dziennik „Wall Street Journal”, opublikowanych przez Radę Państwową ChRL, wartość wymiany handlowej pomiędzy ChRL i krajami Afryki wyniosła w tym roku 114 mld USD ${ }^{82}$. Według informacji Urzędu Statystycznego ChRL (Zhonghua Renmin Gongheguo Tongjiju) w tym samym roku wartość handlu chińsko-afrykańskiego wyniosła 127,05 mld USD, z czego 59,95 mld przypadło na afrykański import z Chin, a 67,09 mld na eksport do Państwa Środka ${ }^{83}$. Wielkość wymiany handlowej między ChRL i krajami Afryki z chińskiego punktu widzenia nie należy jednak do największych: dla porównania obroty handlowe między ChRL i USA wyniosły w 2010 r. niemal 457 mld USD ${ }^{84}$, z największym partnerem handlowym Unią Europejską przeszło 364 mld euro ${ }^{85}$, a z krajami Ameryki Łacińskiej 178,6 mld USD ${ }^{86}$.

Największymi eksporterami do Chin są Angola (wartość eksportu w 2010 r. to 22,82 mld USD) - kraj, z którego Chiny importują najwięcej nierafinowanej ropy naftowej i którego są największym partnerem handlowym ${ }^{87}$, oraz Republika

79 Lu Yong, China's Trade Rush with Africa, „Capital Week”, 25.04.2011, http://www.focac. org/eng/zfgx/t820242.htm [dostęp 12.07.2012].

${ }^{80}$ H.G. Broadman. Chinese-African Trade and Investment: The Vanguard of South-South Commerce in the Twenty-First Century, [w:] R.I. Rotberg (red.) China into Africa. Trade, Aid, and Influence, Brookings Institution Press, Washington 2008, s. 88.

81 P. Wonacott. In Africa, U.S. Watches China's Rise. Ethiopia and Zambia Are Among Fans of Continent's New Top Trade Partner; Washington Presses for Accountability, „Wall Street Journal”, 2.09.2011, http://online.wsj.com/article/SB1000142405311190339290457651027183814724 8.html [dostęp 12.07.2012].

82 Ibidem.

${ }^{83}$ Dane za: „China Daily”, 29.06-5.07.2012, s. 5. Błąd rzędu 0,1 mld przy zsumowaniu. W chwili pisania tekstu dane za rok 2010 były najnowszymi opublikowanymi przez stronę chińską.

${ }^{84}$ Dane za: http://www.census.gov/foreign-trade/balance/c5700.html [dostęp 25.07.2012].

85 Dane Komisji Europejskiej, http://trade.ec.europa.eu/doclib/docs/2006/september/tradoc_113366.pdf [dostęp 25.07.2012]. Dane Komisji cyt. za Międzynarodowym Funduszem Walutowym, wartość handlu między ChRL i Chinami szacowano w tym samym roku na niecałe $292 \mathrm{mld}$ euro, tj. (według kursu z grudnia 2010 r.) zaledwie ok. 350 mld USD.

${ }^{86}$ Dane za R. Morris, China: Latin America Trade Jumps, „Latin Business Chronicle”, 9.05.2011, http://www.latinbusinesschronicle.com/app/article.aspx?id=4893 [dostęp 25.07.2012].

87 Chiny zajmują pierwsze miejsce wśród odbiorców angolańskiego eksportu oraz drugie miejsce, za UE, wśród importerów. Dane ze stron Komisji Europejskiej, http://trade.ec.europa.eu/ doclib/docs/2006/september/tradoc_122456.pdf [dostęp 25.07.2012]. 
Południowej Afryki (14,9 mld USD, ChRL jest także największym partnerem handlowym RPA od 2009 r. $)^{88}$. Również w imporcie z RPA dominują surowce mineralne - rudy żelaza (o wartości 5 mld USD w 2011 r., 60\% południowoafrykańskiego eksportu tego surowca), chromu (780 mln USD), manganu (393 $\mathrm{mln}$ USD) oraz ołowiu (115 mln USD). Chiny sprowadzają z RPA także węgiel, metale pospolite, takie jak: żelazo, stal, miedź, nikiel i aluminium. Oprócz surowców RPA eksportuje do ChRL takie towary, jak drewno czy papier, a także, co wyjątkowe wśród afrykańskich partnerów Chin, niewielkie ilości maszyn i sprzętu mechanicznego ${ }^{89}$. Jednak bezprecedensowym, jak zwraca uwagę strona południowoafrykańska, liderem wśród „towarów” sprowadzanych przez ChRL z RPA jest lokalna waluta. W $2010 \mathrm{r}$. Chiny importowały południowoafrykańskie randy (ZAR) o wartości 3,4 mld USD, w trzech pierwszych kwartałach $2011 \mathrm{r}$. zakupiły ZAR o wartości 10,9 mld USD, a zatem przeciętnie miesięcznie skupowały południowoafrykańskie banknoty i monety o wartości 1,1 mld USD. Czyni to z południowoafrykańskiej waluty jedną z najchętniej skupowanych przez $\mathrm{ChRL}^{90}$.

Dwa kolejne miejsca wśród partnerów handlowych Chin na kontynencie afrykańskim zajmowały w 2010 r. Sudan (przed secesją Południowego Sudanu) $-8,63$ mld USD obrotów (import z Chin - 1,95, eksport do Chin 6,68 mld USD) oraz Nigeria - 7,76 mld USD (import z Chin 6,69 mld USD oraz 1,07 mld USD eksportu do Chin) ${ }^{91}$. Jak widać z przytoczonych danych, wszyscy trzej najwięksi partnerzy gospodarczy ChRL w Afryce mają dodatni bilans handlowy w wymianie z Chinami, a czwarta na liście Nigeria była w 2010 r. pierwszych krajem, dla którego stosunek ten był negatywny. Nigeryjskie dane za rok 2011 wskazują jednak, że także temu krajowi udało się uzyskać dodatni bilans w wymianie handlowej z ChRL dzięki wzrostowi eksportu surowców mineralnych, przede wszystkim ropy naftowej i gazu ziemnego do $\mathrm{Chin}^{92}$.

W swojej polityce gospodarczej wobec Afryki ChRL chętnie odwołuje się do obniżki taryf celnych dla produktów importowanych z kontynentu. Stawki celne dla Afryki Subsaharyjskiej już od lat 90 . XX w. były najniższe spośród wszystkich regionów - w 1992 r. wynosiły zaledwie 12\%, a w 2005 r. Chiny zadeklarowały

88 Dane Urzędu Statystycznego ChRL za „China Daily”, 29.06-5.07.2012, s. 5. Zaledwie 10 lat minęło od nawiązania oficjalnych stosunków dyplomatycznych ChRL z RPA do zajęcia przez Chiny pierwszego miejsca wśród partnerów handlowych Południowej Afryki. Za China Becomes South Africa's Biggest Trading Partner, Radio Netherlands International Africa, 28.09.2009, http://www. rnw.nl/africa/article/china-becomes-south-africas-biggest-trading-partner [dostęp 23.07.2012].

89 Dane za J. Stevens, BRIC and Africa. What Next for China-South African Ties?, Africa Macro. Insight \& Strategy, 24.11.2011, https://research.standardbank.com/Search\#/?Preview=1671-D8DF1487E78C41A0ABDBE3897CAD0303 [dostęp 22.07.2012]. To samo źródło podaje, że w 2011 r. RPA stało się największym afrykańskim eksporterem do ChRL, wyprzedzając Angolę. Obecnie brak dostępu do oficjalnych danych chińskich mogących potwierdzić tę informację.

90 Ibidem.

91 Dane Urzędu Statystycznego ChRL za „China Daily”, 29.06-5.07.2012, s. 5.

92 T. Akinmutimi, Nigeria 's Exports to China Rise by N2.09trn, „National Mirror”, 6.01.2012. 
ich obniżenie do 4,9\% ${ }^{93}$. W dokumencie „Afrykańska Polityka Chin” zadeklarowano, że władze chińskie podejmą odpowiednie kroki, by ułatwić dostęp towarów afrykańskich do rynku chińskiego i wywiążą się ze swojego zobowiązania objęcia towarów z najmniej rozwiniętych państw kontynentu całkowitym zwolnieniem z ceł, w celu ,rozwoju i zbalansowania handlu obustronnego i optymalizacji struktury wymiany handlowej"94. Już we wcześniejszym okresie zwolnieniami z ceł objęto ponad 180 produktów z najuboższych krajów Afryki, ale inne towary z tych krajów wciąż objęte były rosnącymi stawkami celnymi ${ }^{95}$. W ,planie działań FOCAC" na lata 2007-2009, przyjętym w czasie szczytu pekińskiego w 2006 r., zadeklarowano zwiększenie liczby towarów z najmniej rozwiniętych krajów Afryki objętych zerową stawką celną ze 190 do 440, z zaznaczeniem, po raz pierwszy, że chodzi o kraje posiadające oficjalne stosunki dyplomatyczne z $\mathrm{ChRL}^{96}$. W ,planie działań" przyjętym na kolejnym szczycie ministerialnym FOCAC w Szarm El-Szejk postępy w tej dziedzinie zostały określone jako ,zadowalające”. Strona chińska zobowiązała się do dalszego poszerzania zakresu polityki bezcłowej dla towarów z najmniej rozwiniętych państw, z ponownym zaznaczeniem ,posiadających oficjalne stosunki dyplomatyczne z ChRL"97. Stopniowo aż 95\% towarów z tych państw miało zostać objęte zerowymi stawkami, począwszy od objęcia 60\% towarów w 2010 r. ${ }^{98}$ Zapis wszedł w życie 1 lipca 2010 r., kiedy Ministerstwo Handlu poszerzyło listę towarów importowanych z najmniej rozwiniętych państw Afryki objętych zerowymi stawkami z 478 do ponad 4700 pozycji ${ }^{99}$.

${ }_{93}$ Ch. F. Bach, W. Martin, J.A. Stevens, China and the WTO: Tariff Offers, Exemptions, and Welfare Implications, s. 20, http://www.friisbach.dk/fileadmin/cfb/publicat/weltwirt/weltwirt.pdf [dostęp 23.01.2013].

94 China's African Policy..., 2.1. Trade.

95 Ali Zafar, The Growing Relationship Between China and Sub-Saharan Africa: Macroeconomic, Trade, Investment, and Aid Links, „The World Bank Research Observer” 2007, vol. 22, no. 1, s. 117.

96 Forum on China-Africa Cooperation Beijing Action Plan (2007-2009), 16.11.2006, http:// www.focac.org/eng/ltda/dscbzjhy/DOC32009/t280369.htm [dostęp 29.01.2013].

${ }_{97}$ Są to: Burundi, Tanzania, Gwinea Bissau, Etiopia, Komory, Ruanda, Gwinea, Benin, Mauretania, Erytrea, Uganda, Togo, Malawi, Lesotho, Sudan, Mozambik, Mali, Dżibuti, Republika Środkowoafrykańska, Sierra Leone, Liberia, Czad, Madagaskar, Zambia, DR Kongo, Gwinea Równikowa. Lista za: Shangwubu: sanniannei jiang zhubu kuoda dui Feizhou guojia mianguanshui daiyu [Ministerstwo Handlu: w ciągu trzech lat stopniowo zostanie rozszerzony zakres zwolnienia z ceł dla państw Afryki], http://finance.ifeng.com/news/20100701/2364524.shtml [dostęp 12.01.2013]. W 2010 r. prowadzono również rozmowy o objęciu programem towarów z czterech kolejnych państw afrykańskich, z myślą o włączeniu ich do jego działań w 2011 r. (Angola, Senegal, Niger i Somalia), http://www.cs.com.cn/xwzx/jsbd/201007/t20100701_2492923.htm [dostęp 2.02.2013].

98 Forum on China-Africa Cooperation Sharm El Sheikh Action Plan (2010-2012), pkt 4.4.3, http://www.focac.org/eng/dsjbzjhy/hywj/t626387.htm [dostęp 12.12.2012].

99 Zhongfang kaishi dui 26 Feizhou zui bu fada guojia 60\% de chanpin shishi mianguanshui zhengce [Strona chińska wprowadza w życie politykę objęcia $60 \%$ towarów z 26 najmniej rozwiniętych państw Afryki polityką zwolnienia z ceł], http://xyf.mofcom.gov.cn/aarticle/j/201008/20100807072819.html [dostęp 14.01.2013]. 
W najnowszym planie działań FOCAC, przyjętym w czasie piątego szczytu ministerialnego w Pekinie, strona chińska zobowiązała się do dalszego otwierania swojego rynku dla towarów afrykańskich. W planie ponownie znalazł się również zapis o polityce zwolnień z ceł towarów afrykańskich - obecnie ma ona osiągnąć docelowo poziom $97 \%$ towarów pochodzących z najmniej rozwiniętych krajów kontynentu, a dla bardziej efektywnego zarządzania procesami celnymi strona chińska zaoferowała utworzenie chińsko-afrykańskiego mechanizmu konsultacyjnego w tej sferze ${ }^{100}$. Powtarzające się w kolejnych planach i deklaracjach sformułowanie o najmniej rozwiniętych krajach „posiadających oficjalne stosunki dyplomatyczne" z ChRL wskazuje na to, że mechanizm zwolnienia z ceł jest politycznie wykorzystywany przez władze chińskie jako zachęta dla kilku państw kontynentu utrzymujących stosunki z Tajpej do ich zerwania. Pomimo że kraje te są niewielkie i niezbyt zasobne w surowce Pekin wykorzystuje politykę celną do całkowitego wypchnięcia Republiki Chińskiej z kontynentu.

W celu pobudzenia afrykańskiego eksportu do Chin i zainteresowania chińskich odbiorców towarami z kontynentu w ,planie działań” z Szarm El-Szejk przewidziano utworzenie na terenie Chin afrykańskiego centrum handlowego. W maju 2011 r. doszło do otwarcia tej instytucji pod nazwą „Centrum Wystawienniczo-Handlowe Produktów Afrykańskich” (Feizhou Chanpin Zhanxiao Zhongxin, African Products Trade and Exhibition Center) w mieście Wuyi w prowincji Zhejiang ${ }^{101}$. Centrum, wchodzące w skład Międzynarodowego Centrum Handlowego miasta Wuyi ma powierzchnię 5 tys. $\mathrm{m}^{2}$, a swoje pawilony otworzyły w nim do tej pory m.in. RPA, Kamerun, Czad, Ruanda i Tanzania ${ }^{102}$.

\section{Inwestycje bezpośrednie}

Chińskie bezpośrednie inwestycje zagraniczne (FDI) w Afryce są blisko związane z kwestiami handlu i pomocy rozwojowej i znacząco rosły w pierwszej dekadzie obecnego stulecia wraz ze wzrostem wymiany handlowej ChRL z Afryką. Do niedawna inwestycje w Afryce pozostawały jednak na stosunkowo niewysokim poziomie w porównaniu z całością chińskich FDI - w 2007 r. stanowiły $5,9 \%$ wszystkich inwestycji zagranicznych ${ }^{103}$. Nie były również znaczącą częścią

100 Zhong-Fei Hezuo Luntan diwujie Buzhangji Huiyi - Beijing Xingdong Jihua (2013-2015) [V konferencja ministerialna FOCAC, pekiński plan działań na lata 2013-2015], pkt 4.4.5, http:// www.focac.org/chn/ltda/dwjbzzjh/hywj/t954617.htm [dostęp 3.02.2013]. Tekst angielski http:// www.focac.org/eng/ltda/dwjbzjjhys/hywj/t954620.htm [dostęp 3.02.2013].

101 Feizhou Chanpin Zhanxiao Zhongxin, http://finance.ifeng.com/roll/20111215/5278413. shtml [dostęp 12.10.2012].

${ }_{102}$ Dane $\mathrm{z}$ oficjalnej strony Centrum: http://www.afrtrade.com/companylist.html?cpage=1 [dostęp 12.01.2013].

103 M.-F. Renard, China 's Trade and FDI in Africa, Series N ${ }^{\circ} 126$, African Development Bank, Tunis 2011, s. 18. 
wszystkich inwestycji zagranicznych w Afryce, stanowiąc w 2007 r. zaledwie 3\% FDI na kontynencie ${ }^{104}$. W 2009 r. wśród 20 największych odbiorców chińskich inwestycji znajdowały się zaledwie dwa kraje afrykańskie: RPA na 7. miejscu - z 2,3 mld USD i Zambia na 20. miejscu - z 843 mln USD ${ }^{105}$. Jednak tempo przyrostu wartości chińskich FDI w Afryce było znaczące i według Ministerstwa Handlu ChRL przez pierwszą dekadę XXI w. wynosiło $46 \%$ rocznie ${ }^{106}$. Związane jest to z przyjęciem w $2001 \mathrm{r}$. polityki zouchuqu i wprowadzenia w jej rezultacie wielu ułatwień administracyjnych i usprawnień dla chińskich inwestorów lokujących kapitał poza granicami kraju, celem przekształcenia ich w konkurencyjnych graczy na rynku międzynarodowym ${ }^{107}$. Ważną przyczyną szybkiego przyrostu chińskich inwestycji w Afryce i ich ogólnego sukcesu jest również korzystny dla inwestorów, bardzo liberalny klimat na kontynencie, wytworzony pod wpływem nacisków ze strony zachodnich instytucji finansowych ${ }^{108}$. Wykorzystując niejako narzucone Afryce przez Zachód warunki inwestycyjne, Chiny korzystają z tych możliwości. Jak zauważa Peter Kragelund, gdyby nie ten liberalny klimat, chińskie firmy „nie byłyby w stanie kontrolować całego swojego pionowo zorganizowanego łańcucha finansowego, lecz musiałyby szukać porozumienia z innymi firmami" ${ }^{109}$.

W „Afrykańskiej Polityce Chin” z 2006 r. rząd chiński zadeklarował, że „zachęca i wspiera inwestycje i interesy chińskich przedsiębiorstw w Afryce i nadal będzie udzielał preferencyjnych pożyczek i kredytów kupieckich w tym celu. Rząd chiński jest gotowy poszukiwać nowych kanałów i nowych rozwiązań do promowania współpracy inwestycyjnej z państwami afrykańskimi i będzie kontynuował formułowanie i usprawnianie odpowiednich rozwiązań. Będzie również udzielał pomocy, usług i oferował udogodnienia. Afrykańskie przedsiębiorstwa są zachęcane do inwestowania w Chinach. Rząd chiński będzie kontynuował negocjacje w celu ich zamknięcia i wprowadzenia w życie Układu o dwustronnych ułatwieniach i ochronie inwestycji oraz Układu o unikaniu podwójnego opodatkowania. Obie strony powinny współpracować w celu stworzenia środowiska sprzyjającego inwestycjom i współpracy oraz chronić prawa i interesy inwestorów z obu stron" ${ }^{110}$.

104 Ibidem.

105 N. Salidjanova, Going Out: An Overview of China's Outward Foreign Direct Investment, USCC Staff Research Report, s. 15, http:/www.uscc.gov/researchpapers/2011/GoingOut.pdf [dostęp 2.02.2013].

106 M.-F. Renard, China's Trade and FDI in Africa...

107 P. Kragelund, Knocking on a Wide-open Door: Chinese Investments in Africa, „Review of African Political Economy" 2009, no. 122, s. 485.

108 Ibidem, s. 949.

109 Ibidem.

110 China's African Policy, (2) Investment. 
W początkach drugiej dekady XXI w. rozwiązania polityki zouchuqu, jak się wydaje, przyniosły bardzo dobre rezultaty dla chińskich inwestycji na kontynencie afrykańskim. W 2012 r. Afryka Subsaharyjska (bez zaliczanego również do tego regionu Sudanu) stała się drugim, po Ameryce Północnej, największym regionalnym odbiorcą chińskich FDI, przyjmując (według niepełnych danych, nieobejmujących wszystkich państw obszaru) 97,8 mld USD ${ }^{111}$. Wśród największych odbiorców chińskich inwestycji FDI na kontynencie znalazły się Nigeria (15,6 mld USD), RPA (8,6 mld USD) i Demokratyczna Republika Kongo (7,8 mld USD) ${ }^{112}$. Jak pokazuje analiza tych inwestycji, koncentrują się one w sektorze surowcowym i energetycznym. Chiny postrzegają Afrykę jako wielkie źródło strategicznie ważnych surowców, od ropy naftowej, przez rzadkie metale szlachetne, po stal i miedź, których potrzebują do osiągnięcia założonych celów rozwojowych do 2020 r., co powoduje, że obecnie chińskie inwestycje wykazują tendencję do koncentrowania się głównie $\mathrm{w}$ tych sektorach ${ }^{113}$. Nie są to jedyne sfery zainteresowania chińskich inwestorów, co przeczy nieco stereotypowemu postrzeganiu inwestycji chińskich w Afryce jako ograniczających się tylko i wyłącznie do zasobów naturalnych i energetycznych. W 2012 r. w Nigerii zainwestowano 8,2 mld USD w sektor energetyczny, ale 3,8 mld USD w sektor transportowy, 2,8 mld USD w nieruchomości i $400 \mathrm{mln}$ USD w technologie ${ }^{114}$. W RPA aż 5,9 mld USD pochłonęły inwestycje w sektor finansowy, a pozostałe 2,7 mld USD w sektor wydobycia metali i zaledwie $100 \mathrm{mln}$ USD w transport ${ }^{115}$. Kongo przyjęło zaś większą część swoich chińskich FDI w sektorze wydobycia metali - 7,2 mld USD, przy zaledwie $660 \mathrm{mln}$ USD w sektorze energetycznym ${ }^{116}$.

W 2012 r. największą chińską inwestycją w Afryce było odkupienie od francuskiego koncernu naftowego Total 20\% udziałów w przybrzeżnym polu naftowym Ulsan w Nigerii przez Sinopec za ok. 2,5 mld USD ${ }^{117}$. Pole to powinno zapewnić chińskiemu koncernowi ok. 36 tys. baryłek ropy dziennie (tj. ok. 10\% całości nigeryjskiej produkcji) po osiągnięciu szczytowej wydajności i zmniejszając

111 Dane ze stycznia 2013 r. za The Heritage Foundation, China Global Investment Tracker data set, [w:] D. Scissors, China's Global Investment Rises: The U.S. Should Focus on Competition, „Backgrounder, no. 2757, 8.01.2013, s. 3, http://thf_media.s3.amazonaws.com/2013/pdf/bg2757. pdf [dostęp 1.02.2013].

112 Ibidem.

113 Yang Xiaoyun, Zhongguo dui Feizhou Zhijie Touzi de Chukou Xiaoying Fenxi [Analiza efektów eksportowych chińskich inwestycji bezpośrednich w Afryce], „Tequ Jingji”, Maj 2010, s. $87-88$.

114 Dane za The Heritage Foundation China Global Investment Tracker Interactive Map, http://www.heritage.org/research/projects/china-global-investment-tracker-interactive-map [dostęp 5.02.2013].
115 Ibidem.
116 Ibidem.
117 Dane za ibidem. 
koszty własne Sinopec ${ }^{118}$. Inwestycja ta dobrze obrazuje motywacje państwowych przedsiębiorstw, takich jak Sinopec, przy podejmowaniu decyzji inwestycyjnych. Obecnie specjaliści szacują, że Sinopec musi płacić na rynku międzynarodowym dwukrotnie więcej za baryłkę ropy niż wynosi średnia światowa ${ }^{119}$. Zapewniając sobie dostęp do własnych źródeł wydobycia, strona chińska ma nadzieję, że uda się jej uzyskać tańszy surowiec i strategiczny dostęp do niego. Motywacje te są tak silne, że chińskie koncerny naftowe są skłonne płacić za udziały w polach naftowych ceny wyższe niż rzeczywiste ${ }^{120}-\mathrm{w}$ przypadku pola Ulsan cena zapłacona przez Sinopec była wyższa o ok. $400 \mathrm{mln}$ USD od tej, której oczekiwał pierwotnie Total ${ }^{121}$. Przyczyny, dla których chińskie spółki naftowe inwestują w złoża, brak przejrzystości tych transakcji, skłonność do przepłacania oraz relatywny brak troski o opłacalność przedsięwzięć powodują, że przedsiębiorstwa te postrzegane są jako polityczne narzędzia władz chińskich ${ }^{122}$.

Metody działania chińskich spółek w tym sektorze ulegają jednak zmianom, a ich działania coraz wyraźniej wymuszane są uwarunkowaniami rynkowymi. Pomimo państwowej własności i kontroli koncerny takie jak Sinopec i CNPC (China National Petroleum Corporation) nie otrzymują od władz poleceń inwestycyjnych, lecz same inicjują poszukiwania zagranicznych możliwości inwestycyjnych, dla których uzyskują następnie zgodę Ministerstwa Handlu Zagranicznego i Współpracy Międzynarodowej i/lub Państwowej Komisji Rozwoju i Reform ${ }^{123}$. W szczególnie delikatnych przypadkach mogą jednak liczyć na wsparcie dyplomatyczne ze strony państwa, choć udział Ministerstwa Spraw Zagranicznych $\mathrm{w}$ ich inicjatywach inwestycyjnych jest niewielki ${ }^{124}$. Istnieje również mechanizm konsultacyjny między spółkami naftowymi, pozwalający „,rozdzielić” między nie planowane inwestycje, ale władze państwowe i KPCh nie ingerują w jego pracę ${ }^{125}$.

Choć władze chińskie nie ingerują w konkretne inicjatywy inwestycyjne wielkich przedsiębiorstw, dając im swobodę w wyszukiwaniu odpowiednich możliwości, pozostają one narzędziami politycznymi działającymi na rzecz bezpieczeństwa energetycznego i surowcowego ChRL. Jako wyspecjalizowane organizacje podporządkowane państwu cieszą się jego zaufaniem, zastrzega sobie ono jednak prawo ostatecznego zatwierdzenia transferu kapitału do inwestycji. Powoduje

118 T. Patel. Total Sells Nigeria Oil Field to Sinopec for $\$ 2.5$ Billion, http://www.bloomberg.com/news/2012-11-19/total-sells-nigeria-oil-field-to-sinopec-for-2-5-billion.html [dostęp 1.02.2013].

119 Ibidem.

120 M. Meidan, China's Africa Policy..., s. 87.

121 T. Patel, Total Sells Nigeria Oil Field to Sinopec...

${ }_{122}$ M. Meidan, China's Africa Policy..., s. 87. Zob. też: P. Kragelund, Knocking on a Wide-open Door..., s. 485-486.

123 M. Meidan, China's Africa Policy..., s. 87.

${ }^{124}$ Ibidem.

125 Ibidem. 
to stałe napięcia pomiędzy potrzebami koncernów - generowania kosztów i potrzebami władz - zapewnienia krajowi dostępu do surowców ${ }^{126}$.

Wielkie chińskie koncerny energetyczne inwestujące za granicami kraju, w tym w Afryce, bywają oskarżane o nieuczciwe praktyki biznesowe, wykorzystujące korupcję panującą wśród afrykańskich elit. Jednym z przykładów takich niejasnych zachowań owych firm może być sprawa kontraktu i inwestycji Sinopec, wartej 800 mln USD, w Ghana National Gas w 2012 r. Towarzyszą temu kontrowersje wywołane przez rzekomo zawyżone wyceny, przedstawione przez Sinopec, za budowane zakłady gazownicze i podwodny gazociąg łączący pole naftowe Jubilee z zakładami ${ }^{127}$. Wyższa niż początkowo deklarowana przez Sinopec cena m.in. za elementy gazociągu miała wziąc się z dodatkowych ukrytych kosztów, wynikających z dokonania zakupu segmentów gazociągu przez Sinopec u własnej spółki-córki zarejestrowanej w Dubaju ${ }^{128}$. Kontrowersje w parlamencie w Akrze wywołała też pożyczka w wysokości 3,5 mld USD z China Development Bank, wynegocjowana przez władze Ghany na kontrakt Sinopecu bez jego zgody. Opozycja oprotestowała rozpoczęcie przez chiński koncern prac przy zakładach gazowniczych i gazociągu bez zgody parlamentu, jednak rządzący Narodowy Kongres Demokratyczny (NDC), którego ważni członkowie stoją na czele Ghana National Gas, uważa, że nie jest ona potrzebna ${ }^{129}$.

Sprawa inwestycji w ghańskie pola gazowe i kontraktu Sinopecu przyczyniła się do wzmocnienia negatywnego odbioru chińskich inwestycji w tym kraju przez opozycję i organizacje pozarządowe. W październiku 2012 r. w Ghanie wybuchł skandal, gdy ujawniono bliskie związki rządzącej partii z prywatnym chińskim koncernem telekomunikacyjnym Huawei. Miał on m.in. finansować w Chinach produkcję gadżetów partyjnych, „wartych miliony USD”, dla NDC i prezydenta Johna Mahamy, co jest sprzeczne z ghańskim prawem, zakazującym jakiegokolwiek finansowania działalności politycznej w kraju przez cudzoziemców ${ }^{130}$. Huawei miała też wpływać na przyznanie jej przez Ministerstwo Komunikacji i Biuro Bezpieczeństwa Narodowego kontraktów telekomunikacyjnych. Firma ma również opłacać podróże i przeloty polityków NDC, a jej związki z rządzą-

126 Xin Ma, P. Andrews-Speed, The Overseas Activities of China's National Oil Companies: Rationale and Outlook, ,Minerals and Energy” 2006, no. 1, s. 21.

127 Chinese Cheat in Gas Project, http://www.reportingoilandgas.org/2012/09/17/chinesecheat-in-gas-project/ [dostęp 2.02.2013).

128 Ibidem.

129 Alarm Blow over 850m\$ Gas Project, „Daily Guide”, 17.09.2012, http://www.ghanaweb. com/GhanaHomePage/NewsArchive/artikel.php?ID=250746 [dostęp 2.02.2013).

130 William Nana Yaw Beeko, Red Flag Over Chinese Huawei Operations, 16.10. 2012, http:// www.modernghana.com/news/424335/1/red-flag-over-chinese-huawei-operations.html [dostęp 2.02.2013]. 
cą od 1992 r. partią określa się jako bardzo bliskie ${ }^{131}$. Innym niekorzystnym dla wizerunku Chin w Ghanie i Afryce doniesieniem jest informacja o nielegalnej działalności dwóch chińskich firm górniczych w Minti, prowadzącej do zniszczenia upraw kakaowców, podstawowego źródła dochodu dla miejscowej ludności. Działalność ta ma być możliwa, ponieważ Chińczycy (i Hindusi) „kupili zgodę miejscowych wodzów"132.

Na przykładzie chińskiej obecności inwestycyjnej w Ghanie widać, że swój kapitał na kontynencie lokują nie tylko wielkie państwowe koncerny energetyczne, ale również przedsiębiorstwa prywatne, takie jak Huawei. Niezależnie od kontrowersji, jakie budzi działalność chińskich przedsiębiorstw w Afryce, ich liczba stale rośnie, a wśród nich znajdują się firmy o zróżnicowanej skali i strukturze własnościowej. Analitycy gospodarczy przedstawiają m.in. następującą typologię inwestorów z ChRL w Afryce:

1. W większości będące własnością państwową przedsiębiorstwa kontrolowane przez władze centralne, finansowane poprzez kredyty państwowego Exim Banku. Aktywne głównie w sektorze surowcowym, projektach infrastrukturalnych i budowlanych. Ich działalność wymaga formalnych porozumień na poziomie międzypaństwowym, które w większości przypadków są dobrze udokumentowane, choć nie zawsze przejrzyste.

2. Przedsiębiorstwa należące do władz prowincjonalnych, lojalne zazwyczaj wobec swoich bezpośrednich zwierzchników we władzach prowincji, a nie w rządzie centralnym. Również one korzystają z finansowania Exim Banku i działają $\mathrm{w}$ tych samych sektorach co przedsiębiorstwa $\mathrm{z}$ kategorii 1. Generalnie korzystają $\mathrm{z}$ rozmaitych form współpracy między władzami prowincji, skąd pochodzą, i rządami afrykańskimi.

3. Firmy zarejestrowane w Chinach i w Afryce, działające głównie w sektorze produkcyjnym i w usługach, działają niezależnie od chińskiego rządu centralnego, ale mogą być wspierane przez władze swojej prowincji.

4. Firmy zarejestrowane tylko w Afryce, działające głównie w branżach przemysłu lekkiego i usług, finansowane ze środków własnych, niezależne od chińskich władz centralnych i prowincjonalnych, opierające się na kontaktach rodzinnych ${ }^{133}$.

Państwo chińskie wspiera inwestorów trzech pierwszych kategorii za pomocą kredytów i pożyczek bezpośrednio przez Bank of China (Zhongguo Yinhang) i pośrednio przez kontrolowane przez siebie banki komercyjne, takie jak Exim Bank,

131 Ibidem.

132 Illegal Chinese, Indian miners Take over Minti, „Daily Guide”, 8.02.2013, http://www. modernghana.com/news/444393/1/illegal-chinese-indian-miners-take-over-minti.html [dostęp 10.02.2013].

133 Typologia inwestorów chińskich za R. Kaplinsky, M. Morris, Chinese FDI in Sub-Saharan Africa: Engaging with Large Dragons, „European Journal of Development Research” 2009, no. 21, s. 553. 
China Development Bank oraz Agricultural Bank of China (Zhongguo Nongye Yinhang $)^{134}$. Ten ostatni zarządza swoimi afrykańskimi operacjami z otworzonego w lutym 2012 r. oddziału w Londynie ${ }^{135}$. China Development Bank posiada od 2010 r. specjalny program kredytowy w Afryce, adresowany do małych i średnich przedsiębiorstw, które chcą zdobyć finansowanie i stworzyć na kontynencie rynki dla swoich usług ${ }^{136}$. Do końca $2011 \mathrm{r}$. z programu tego sfinansowano ponad tysiąc projektów i stworzono 50 tys. miejsc pracy w ponad 25 krajach Afryki ${ }^{137}$.

Szczególnie aktywny na kontynencie jest Exim Bank, który według szacunków poświęca od jednej trzeciej do połowy swojej aktywności finansowej przedsięwzięciom w Afryce, będąc w regionie subsaharyjskim źródłem 92\% kredytów dla chińskich inwestycji infrastrukturalnych ${ }^{138}$. Agencja ratingowa Fitch szacuje, że w latach 2001-2010 Exim Bank udzielił w Afryce Subsaharyjskiej kredytów o wartości 67,2 mld USD, tj. o 12,5 mld więcej niż kredyty w regionie udzielone w tym okresie przez Bank Światowy ${ }^{139}$. W 2012 r. bank ten udzielił pożyczki w wysokości 500 mln USD dla rządu Republiki Kongo na odbudowę dzielnicy zniszczonej przez eksplozję składu amunicji, pożyczki w tej samej kwocie władzom Kamerunu na budowę $240 \mathrm{~km}$ drogi między stolicą kraju Yaounde i jego największym miastem Doualą oraz 120 mln USD dla władz Czadu na projekty elektryfikacyjne ${ }^{140}$. Exim Bank jest również największym nie-afrykańskim udziałowcem w Afrykańskim Banku Eksportowo-Importowym (Afreximbank), a Liu Liange, jeden z wicedyrektorów Exim Banku, zasiada od 2007 r. w 12-osobowej radzie nadzorczej Afreximbanku ${ }^{141}$. W maju 2009 r. Exim Bank otworzył dla Afreximbanku linię kredytową w wysokości 100 mln USD, która według Exim Banku ,silnie wspomogła afrykański import wyposażenia, szczególnie telekomunikacyjnego"142. W 2010 r. w Pekinie odbyło się pierwsze poza Afryką posiedze-

${ }^{134}$ China Development Bank został utworzony w 1994 r. i znajduje się pod bezpośrednią jurysdykcją Rady Państwowej ChRL, http://www.swfinstitute.org/swfs/china-africa-development-fund/ [dostęp 2.02.2013].

135 Zhang Hong, Agricultural Bank of China Opens London Branch, http://english.caixin. com/2012-02-09/100354907.html [dostęp 4.02.2013].

136 M. Cohen, China's EXIM Lend More to Sub-Sahara Africa Than World Bank, Fitch Says, 28.12.2011, http://www.bloomberg.com/news/2011-12-28/china-exim-loans-to-sub-sahara-africa-exceed-world-bank-funds-fitch-says.html [dostęp 2.02.2013].

137 Ibidem.

${ }_{138}$ S. Le Belzic, China's Exim Bank: Africa's Largest Financier Looks for an Even Bigger Role, „The Africa Report”, 25.10.2012, http://www.theafricareport.com/north-africa/chinas-exim-bank-africas-largest-financier-looks-for-an-even-bigger-role.html [dostęp 30.01.2013].

139 S. Rabinovitch, China: A New Way of Lending, „Financial Times”, 23.09.2012.

140 S. Le Belzic, China's Exim bank... Jak zauważa autor, są to jedynie projekty ujawnione przez Exim Bank, który publikuje bardzo ogólne statystyki swoich pożyczek w dorocznych raportach. Działania banku określa on jako „nieprzejrzyste”.

$141 \mathrm{http} / / /$ forum.eximbank.gov.cn/forum/channel/afreximbank.shtml [dostęp 9.02.2013].

142 Ibidem. 
nie rady nadzorczej afrykańskiego banku, którego celem miało być „wzmocnienie współpracy z chińskimi instytucjami finansowymi, takimi jak Exim Bank, Development Bank of China i firmami chińskimi"143. Symbolem roli chińskiego banku w Afreximbanku może być fakt, że w lipcu 2012 r. 19. ogólne posiedzenie udziałowców odbyło się po raz pierwszy poza Afryką w Pekinie ${ }^{144}$.

Jak zauważa Greg Chin, główny analityk ds. Chin w Center for International Governance Innovation, Chiny wciąż postrzegają siebie jako członka globalnego Południa i dlatego nie chcą koordynować własnej polityki kredytowej w Afryce z Bankiem Światowym, który cieszy się na Południu złą reputacją z powodu preferencyjnych kredytów ${ }^{145}$. Koncentrując swoją politykę kredytową na sektorach wydobycia, banki chińskie wspierają jednak inne branże w państwach afrykańskich niż pożyczkodawcy z Banku Światowego, tym samym pozytywnie przyczyniając się do rozwoju gospodarek na kontynencie. Państwa afrykańskie czasami wybierają pożyczki chińskie, nawet jeśli ich warunki są gorsze niż te oferowane przez Bank Światowy i IMF ${ }^{146}$. Zdaniem Grega China, ChRL preferuje bardziej bilateralną politykę kredytową niż Bank Światowy i Międzynarodowy Fundusz Monetarny, lecz nie chce zburzyć istniejącego porządku, a raczej go zreformować poprzez decentralizację i regionalizację. Chęć udziału Chin, na własnych warunkach, w międzynarodowym systemie finansowania pomocy rozwojowej widać m.in. w zwiększeniu przez Chiny finansowania Azjatyckiego Banku Rozwoju i zorganizowaniu w 2007 r. generalnego posiedzenia Afrykańskiego Banku Rozwoju w Szanghaju ${ }^{147}$.

Finansowanie z Exim Banku i Development Bank of China pomaga również sprawie umiędzynarodowienia chińskiej waluty renminbi ${ }^{148}$. Zambijski oddział Bank of China (pierwsza chińska instytucja finansowa na kontynencie założona w 1997 r. i piąty pod względem wielkości kapitału bank w Zambii) od 2011 r. prowadzi część swoich operacji w banknotach renminbi, dążąc do roli „banku clearingowego renminbi w Afryce" ${ }^{149}$.

Chińskie banki w Afryce wspierają swoimi kredytami zarówno chińskie przedsiębiorstwa chcące inwestować na kontynencie, jak i lokalne rządy, stając się tym samym nie tylko wsparciem dla innych inwestorów, ale również wielkimi inwestorami. Według raportu Fitch Rating „brak politycznych zobowiązań,

143 Ibidem.

144 Ibidem.

145 S. Rabinovitch, China: A New Way of Lending...

146 Ibidem. Tak było m.in. w Angoli i Czadzie.

147 Ibidem.

148 S. Le Belzic, China's Exim Bank...

149 Bank of China Launches RMB Notes Business in Africa, 3.08.2011, http:/www.boc.cn/ en/bocinfo/bi1/201108/t20110817_1495400.html [dostęp 2.02.2013]. W tym samym tekście Bank of China podaje, że łączne aktywa jego zambijskiego oddziału zwiększyły się w latach 2001-2010 o 2488\%, co dało mu pozycję najszybciej rozwijającego się banku w Zambii. 
konkurencyjne oprocentowanie oraz elastyczne terminy spłat" powodują, że pożyczki z chińskich banków stanowią atrakcyjną alternatywę dla finansowania ze źródeł tradycyjnych na Zachodzie, szczególnie dla krajów uzależnionych od pomocy międzynarodowej, jak Ghana i Mozambik ${ }^{150}$.

W kontekście finansowania chińskich inwestycji w Afryce rosnącą rolę pełni powołany w 2007 r. Chińsko-Afrykański Fundusz Rozwojowy (patrz wyżej), którego celem jest ,zachęcanie i wspieranie coraz większej liczby chińskich przedsiębiorstw do inwestowania w Afryce" ${ }^{151}$. Fundusz został stworzony przez China Development Bank jako jego oddział odpowiedzialny za inwestycje kapitałowe ${ }^{152}$. Działa on w oparciu o mechanizmy rynkowe i oferuje chińskim przedsiębiorstwom pomoc $\mathrm{w}$ zarządzaniu inwestycjami i ryzykiem, pomaga im w zidentyfikowaniu możliwości inwestycyjnych oraz świadczy konsultacje finansowe ${ }^{153}$. Wspiera również przedsiębiorstwa afrykańskie w poszukiwaniu partnerów chińskich, a do ich obsługi utworzył trzy afrykańskie biura w Etiopii, RPA i Zambii ${ }^{154}$. Fundusz deklaruje, że dzięki rygorystycznemu przestrzeganiu procedur i oceny ryzyka inwestycje poczynione za jego pośrednictwem są obarczone niskim ryzykiem i gwarantują korzystne zwroty ${ }^{155}$. Według słów wicedyrektora Funduszu Hu Zhironga, jego celem jest ,połączenie z międzyrządowymi projektami pomocowymi i pomoc większej liczbie chińskich firm w »wyjściu na zewnątrz»" ${ }^{156}$. $\mathrm{Hu}$ przekonuje, że Fundusz jest obecnie zainteresowany nie tylko inwestycjami w sektorze energetycznym i surowcowym, ale również w przemyśle lekkim, nowej energii i rolnictwie ${ }^{157}$. Fundusz miał do tej pory zainwestować w przeszło 50 projektów o wartości przeszło 1,7 mld USD ${ }^{158}$. W 2012 r. ogłosił m.in., że dzięki jego finansowaniu w RPA powstanie warty 100 mln USD park przemysłowy spółki China First Automobile Works (Diyi Qiche Jituan), największy w Afryce ${ }^{159}$. Jak pisze autor tekstu zamieszczonego w czasopiśmie finansowym „Caixin”, a co

${ }_{152}$ D. Brautigam, China Africa Development Fund Not Attractive Enough in China, 24.05.2012, http://www.chinaafricarealstory.com/2012/05/china-africa-development-fund-not.html [dostęp 1.02.2013].

153 Investment Philosophy...

${ }_{154}$ Ding Qingfen, China-Africa Development Fund Sets New Aims for Africa, „China Daily”, 13.04.2012.

150 M. Cohen, China's EXIM...

151 Investment Philosophy, http://www.cadfund.com/en/NewsInfo.aspx?NId=400 [dostęp

155 Ibidem.

156 Facing Risks, Sino Fund Gets Forex for Africa, „Caixin”, 27.04.2012, http://china-wire. $\operatorname{org} / \mathrm{p}=19982$ [dostęp 1.02.2013].

157 Ding Qingfen, China-Africa Development...

158 Ibidem. Na stronie internetowej Fundusz nie podaje szczegółowych danych o swoich inwestycjach, a ostatnie wiadomości w tej sekcji opublikował w $2011 \mathrm{r}$.

159 Ibidem. 
potwierdza Deborah Brautigam, działania Funduszu wskazują, że Chiny w swojej afrykańskiej polityce podążają ścieżką wytyczoną w latach 80 . XX w. przez Japonię - od eksportu produktów do eksportu kapitału ${ }^{160}$.

Pomimo deklarowanych zadań i usług Fundusz nie funkcjonuje bezproblemowo. Nie udało mu się m.in. zebrać 2 mld USD na rynkach kapitałowych i środki te China Development Bank musiał uzyskać z budżetu państwa, po uzyskaniu zgody Rady Państwowej w marcu 2012 r., po dwuletnich staraniach ${ }^{161}$. Jak zauważyło „Caixin”, Fundusz nie zdołał zdobyć przychylności chińskich przedsiębiorców, m.in. przez fakt, że zachowuje sobie prawo do kontroli akcji inwestycji przez okres pięciu lat ${ }^{162}$. Może jednak pełnić użyteczną rolę dla władz chińskich, które mogą wymusić na nim zaangażowanie się w politycznie ważne inwestycje, do czego nie udaje im się nakłonić państwowych banków ${ }^{163}$. Tak było m.in. w przypadku inwestycji w kopalnię w Liberii, gdzie Fundusz, zmuszony przez państwo chińskie, przejął kontrakt zawarty z rządem lokalnym przez prywatną spółkę chińską, której nie udało się wypełnić swoich zobowiązańn ${ }^{164}$.

Choć chińskie inwestycje bezpośrednie w Afryce wywołują wiele kontrowersji i faktycznie w dużej mierze są spowodowane potrzebą zapewnienia sobie dostępu do surowców, to polityka inwestycyjna ChRL i, szerzej cała jej afrykańska polityka spowodowała, że Chiny postrzegane są w Afryce często jako mniej egoistyczne niż Zachód. Ich retoryka wzajemnej pomocy i współprzynależności do ubogiego globalnego Południa prowadzi do postrzegania wysiłków Pekinu na rzecz rozwoju gospodarczego i przemysłowego Afryki, w ramach tzw. konsensusu pekińskiego, jako szczerych i rzeczywistych ${ }^{165}$.

\section{Pomoc rozwojowa}

Jednym z najważniejszych i historycznie najstarszych narzędzi chińskiej polityki wobec kontynentu afrykańskiego jest pomoc rozwojowa, budząca obecnie duże kontrowersje w świecie zachodnim. Chińska Republika Ludowa odwołuje się do tego narzędzia w swojej polityce zagranicznej niemal od samego początku istnienia i od początku relacji z państwami Afryki jako do przykładu globalnej solidarności państw ubogiego Południa. Pierwszymi państwami w Afryce, które

160 D. Brautigam, China Africa Development Fund...

161 Facing Risks... Fundusz wciąż nie osiągnął 5 mld USD kapitału deklarowanych przez Wen Jiabao w czasie szczytu pekińskiego w 2006 r. Jego obecny kapitał wynosi 3 mld USD.

162 Ibidem.

163 D. Brautigam, China Africa Development Fund...

164 Ibidem.

165 B. Sautman, Yan Hairong, Friends and Interests: China's Distinctive Links with Africa, „African Studies Review”, 2007, vol. 50, no. 3, s. 81. 
stały się odbiorcami chińskiej pomocy, były Algieria (1958) i Egipt (1959) ${ }^{166}$. Do 1975 r. ChRL miała w Afryce więcej programów pomocowych niż USA i tendencja ta utrzymuje się do dziś ${ }^{167}$. ChRL, podobnie jak USA, i inaczej niż inni dawcy pomocy, prowadzi niezwykle rozległy program pomocy, obejmujący niemal wszystkie państwa (w tym te, w których dochód per capita jest wyższy niż w Chinach), z którymi nawiązała stosunki dyplomatyczne, i niemal wszystkie sektory i projekty zróżnicowane pod względem skali ${ }^{168}$. W latach 70 . XX w., kiedy ChRL rywalizowała na arenie międzynarodowej z ZSRR o przewodnictwo w trzecim świecie i z Republiką Chińską na Tajwanie o uznanie dyplomatyczne państw afrykańskich, chińska pomoc koncentrowała się na wielkich projektach inżynieryjnych i politycznych, takich jak kolej Tanzańsko-Zambijska (TAZARA). Decyzję o pomocy w budowie tej linii, łączącej port w Dar Es-Salam z zambijskim regionem wydobycia miedzi, podjęto $\mathrm{w}$ Chinach pomimo trwającej rewolucji kulturalnej w 1968 r. i ukończono w 1975 r. Do dziś pozostaje ona największym pojedynczym projektem pomocowym sfinansowanym przez Chiny za pomocą niskooprocentowanej preferencyjnej pożyczki (wg źródeł chińskich nieoprocentowanej w wysokości przeszło $400 \mathrm{mln}$ USD o terminie spłaty 30 lat $\left.{ }^{169}\right)$, a przy jej budowie pracowało ok. 16 tys. robotników i specjalistów z Chin ${ }^{170}$.

Od momentu rozpoczęcia reform gospodarczych w Chinach, a w szczególności od połowy lat 90. XX w., chińska pomoc dla Afryki stała się bardziej racjonalna i skoncentrowana na mniejszych projektach, obliczonych na budowanie „wspólnego dobrobytu”, tj. na tworzenie niezbędnej dla rozwoju Afryki infrastruktury, przy równoczesnym zapewnieniu dla chińskich przedsiębiorstw roli w jej budowie, zarówno poprzez pomoc gospodarczą, jak i inne narzędzia ekonomiczne. Chiny postawiły sobie za cel „wydawać mniej, ale robić więcej” ${ }^{171}$. Pomimo zmniejszenia nakładów finansowych na pomoc dla Afryki w latach 80 . ChRL była już wówczas szóstym największym dawcą pomocy dla kontynentu. W tej dekadzie Chiny zaczęły też eksperymenty z nowymi formami współpracy pomocowej, m.in. tzw. współpracy trójstronnej, gdzie ChRL dostarczała sprzętu i pracowników, a zewnętrzny donator środki na sfinansowanie inwestycji ${ }^{172}$. Obecność chińskich przedsiębiorstw budowlanych i konstrukcyjnych zaangażowanych

166 D. Brautigam, China's Foreign Aid in Africa: What Do We Know?, [w:] China into Africa. Trade, Aid..., s. 199.

167 Ibidem, s. 198.

168 Ibidem, s. 200.

${ }_{169} \mathrm{Hu}$ Jinshan, Feizhou de Zhongguo Xingxiang [Afrykański obraz Chin], Beijing 2010, s. 203.

170 D. Brautigam, The Dragon's Gift. The Real Story of China in Africa, Oxford 2009, s. 40. Książka D. Brautigam jest najszerszym monograficznym opracowaniem kwestii chińskiej pomocy rozwojowej dla Afryki w języku zachodnim.

171 D. Brautigam, China's Foreign Aid in Africa..., s. 203.

172 Ibidem. 
w projekty pomocowe z czasem mogła również przekształcić się w działalność komercyjną, gdy doświadczeni zawodowo w Afryce robotnicy i inżynierowie kontynuowali pracę na kontynencie już na zasadach rynkowych ${ }^{173}$.

Według Deborah Brautigam od 1995 r. ChRL wzmocniła politykę obopólnych korzyści, przekształcając pomoc w jedno ze swoich skutecznych narzędzi ekonomicznych, za pomocą którego zdobywa strategicznych partnerów na kontynencie afrykańskim ${ }^{174}$. Autorka ta zauważa również, że ChRL wykorzystuje pomoc jako narzędzie swojej polityki zarówno dlatego, że przypomina ona tradycyjną chińską praktykę wymiany trybutarnej, jak i dlatego, że jest niezwykle skutecznym i nowoczesnym narzędziem soft power ${ }^{175}$. Wraz ze wzrostem wymiany ekonomicznej z Afryka udziat pomocy w jej ogólnym wymiarze zmalat, ale ChRL nadal korzysta z szerokiej palety narzędzi pomocowych. Znajdujemy tu ${ }^{176}$ :

1. Granty, nieoprocentowane pożyczki i umorzenia zadłużenia - dwa pierwsze narzędzia dominowały wśród chińskiej pomocy rozwojowej do 1995 r. W Biatej księdze chińskiej pomocy, wydanej przez Radę Państwową w 2011 r., rząd chiński zadeklarował, że $40 \%$ pomocy udzielanej przez ChRL ma formę grantów ${ }^{177}$. W tym samym dokumencie władze poinformowały, że w ramach programu umarzania zadłużenia, rozpoczętego w 2000 r., państwom afrykańskim umorzono 2,79 mld USD długów pochodzących z pożyczek nieoprocentowanych.

2. Pożyczki preferencyjne, udzielane wyłącznie na duże projekty (minimum o wartości 2,4 mln USD), w których zapewniony jest minimalny udział towarów chińskich w wysokości $50 \%$. Jedyną instytucją udzielającą chińskich pożyczek preferencyjnych jest Exim Bank, który do 2007 r. udzielił ok. 1,5 mld USD pożyczek na 87 projektów w Afryce. Do 2009 r. Afryka stała się odbiorcą połowy pożyczek preferencyjnych Exim Banku ${ }^{178}$. W 2009 r. rząd chiński zadeklarował, że przeznaczy 10 mld USD na pożyczki preferencyjne dla kontynentu do $2012 \mathrm{r}$.

Te narzędzia finansowe spełniają kryteria pomocy OECD, należy jednak pamiętać, że wiele opracowań włącza do chińskiej pomocy również inne oferowane przez Exim Bank i China Development Bank (który nie ma prawa udzielać pożyczek preferencyjnych) komercyjne narzędzia finansowe, takie jak: kredyty eksportowe, oficjalne pożyczki oprocentowane komercyjnie i strategiczne linie kredytowe dla chińskich przedsiębiorstw ${ }^{179}$. Obliczenia Deborah Brautigam

173 Ibidem, s. 206.

174 Ibidem.

175 Ibidem, s. 201.

176 Za D. Brautigam, Chinese Development Aid in Africa. What, Where, Why, and How Much?, [w:] Rising China Global Challenges and Opportunities, J. Golley, Ligang Song (eds.), Canberra 2011, s. 205-207.

177 Full Text: China's Foreign Aid, http://news.xinhuanet.com/english2010/china/ 2011-04/21/c_13839683_3.htm [dostęp 2.02.2013].

178 L. Corkin. Redefining Foreign Policy..., s. 69.

179 Za D. Brautigam, Chinese Development Aid in Africa..., s. 206. 
wskazują jednak, że chińska pomoc dla Afryki nie jest tak duża, jak podają to często media zachodnie ${ }^{180}$. Bank Światowy w 2009 r. szacował pomoc chińską dla Afryki na 2 mld USD, a chińskie Ministerstwo Finansów na 1,58 mld USD, w porównaniu z 1,2 mld USD w 2008 r. ${ }^{181}$ Najpełniejsze szacunki badaczki mówiły o 2,5 mld USD w 2009 r. ${ }^{182}$ W swoim przemówieniu na V szczycie FOCAC, w lipcu 2012 r., Hu Jintao obiecał otworzenie specjalnej linii kredytowej dla państw afrykańskich o wartości 20 mld USD, w celu wspomożenia ich w budowie infrastruktury, rozwoju rolnictwa, przemysłu oraz małych i średnich przedsiębiorstw ${ }^{183}$.

Instytucjonalnie zwierzchnią strukturą rządową odpowiedzialną za kwestie pomocy dla Afryki jest Ministerstwo Handlu, co wzmacnia tylko jego przewodnią rolę w polityce afrykańskiej Chin (patrz wyżej). Swój udział w polityce pomocowej mają również inne ministerstwa, odpowiadające za właściwe sektory, w których ma być udzielona pomoc - np. rolnictwa, nauki i technologii, zdrowia itp. ${ }^{184}$ Chińska polityka pomocowa obejmuje bowiem m.in. działania zespołów medycznych w Afryce, podległych Ministerstwu Zdrowia, system stypendialny dla studentów i doktorantów z Afryki, podległy Ministerstwu Edukacji, i pomoc techniczną w dziedzinach rolnictwa i rybołówstwa, za które odpowiada Ministerstwo Rolnictwa ${ }^{185}$. Realizując pomoc w tych zakresach, ChRL zbudowała w Afryce ponad 100 szkół, 30 szpitali, 30 centrów antymalarycznych i 20 rolniczych ośrodków pokazowych ${ }^{186}$. W celu usprawnienia współpracy i koordynacji w kwestiach pomocy w 2008 r. ministerstwa handlu, spraw zagranicznych i finansów powołały specjalny międzyministerialny mechanizm administracyjny ${ }^{187}$.

Bardziej skomercjalizowane narzędzia pomocowe, stosowane przez ChRL od lat 90 XX. (łączenie warunków pomocy z koniecznością zatrudnienia chińskich wykonawców, zakupu chińskich materiałów i sprzętu itp.), powodują, że jej altruistyczne motywacje są obecnie w Afryce często podawane w wątpliwość. Jednak, jak wskazują niektórzy autorzy, sposób udzielania pomocy przez Chiny powoduje, że przynosi ona wyraźnie bardziej odczuwalne skutki niż pomoc za-

180 Eadem, China's Foreign Aid in Africa..., s. 198.

181 M. Tan-Mullins, G. Mohan, M. Power, Redefining „Aid” in the China-Africa Context, „Development and Change” 2010, vol. 41(5), s. 863.

182 D. Brautigam, The Dragon's Gift..., s. 168.

183 Open Up New Prospects for A New Type of China-Africa Strategic Partnership, Speech by H.E. Hu Jintao, President of the People's Republic of China At the Opening Ceremony of the Fifth Ministerial Conference of The Forum on China-Africa Cooperation, Beijing, 19.07.2012, http:// www.focac.org/eng/ltda/dwjbzjjhys/zyjh/t953172.htm [dostęp 11.02.2013].

184 Shuaihua Cheng, Ting Cheng, Hui-Ting Lien, China's International Aid Policy and Its Implications for Global Governance, Indiana University Research Center for Chinese Politics \& Business Working Paper \#29, June 2012, s. 6-7.

185 D. Brautigam, China's Foreign Aid in Africa..., s. 201.

186 Open Up New Prospects...

187 Ibidem. 
chodnia, która również stosunkowo niedawno przestała być udzielana w sposób „łączony”188. Również atrakcyjna chińska oferta cenowa produktów, sprzętu i siły roboczej powodują, że ,pomoc wiązana” ChRL przynosi w Afryce korzyści doceniane przez miejscowe władze i ludność ${ }^{189}$. Takie warunki pomocy powodują, że chińskie wsparcie dla rozwoju Afryki przypomina praktyki pomocowe Korei Południowej ${ }^{190}$. Dysponując jednak znacznie większą niż Korea siłą finansową, ChRL poprzez swoją pomoc, nieobarczoną w przeciwieństwie do tej pochodzącej z krajów OECD i rozwiniętego Zachodu, wymaganiami reform politycznych i finansowych, daje państwom Afryki, po raz pierwszy w historii, realną możliwość zróżnicowania swoich źródeł wsparcia finansowego ${ }^{191}$. Co więcej, podkreślana mocno przez Chiny w retoryce współpracy z Afryką i udzielanej jej pomocy zasada nieingerencji w wewnętrzne sprawy państw kontynentu i poszanowania ich suwerenności, powoduje, że miejscowi przywódcy chętniej patrzą na rozwojowy model prezentowany przez Pekin, który nie tylko okazuje się dotychczas bardzo efektywny, ale również nie jest narzucany jako warunek udzielenia pomocy ${ }^{192}$. Chińska retoryka pomocy jako ,pomocy dla dobrobytu ludu” (minsheng yuan$z h u$ ), przeciwstawiana świadomie zachodniej ,pomocy dla demokracji” (minzhu yuanzhu), wydaje się cieszyć na kontynencie, gdzie podstawowymi potrzebami ludności jest obecnie lepiej rozwinięta infrastruktura, dużą popularnością ${ }^{193}$.

\section{Soft power jako narzędzie polityki chińskiej w Afryce}

Od początku swoich relacji z państwami Afryki ChRL szczególnie intensywnie posługuje się narzędziami retorycznymi, obliczonymi na budowę przyjaznych i pełnych zaufania stosunków obustronnych. Jeszcze przed uzyskaniem niepodległości przez większość państw kontynentu Chiny podejmowały liczne delegacje z Afryki, często składające się ze studentów, których przedstawiano najwyższym władzom kraju, co miało budować poczucie, że Chiny Ludowe są sojusznikiem

188 B. Sautman, Yan Hairong, Friends and Interests..., s. 86-87.

189 J.C. Berthelemy, China's Engagement and Aid Effectiveness in Africa, African Development Bank Working Paper Series, no. 129, May 2011, s. 16-17.

190 Ibidem.

191 M. Tan-Mullins, G. Mohan, M. Power, Redefining „Aid”..., s. 875.

192 Ibidem.

${ }_{193}$ Koncepcja minsheng yuanzhu - pomocy, której celem jest „dobrobyt ludu”, dobrze wpisuje się w modernizacyjne tradycje nowoczesnych Chin. Hasłem minsheng, thumaczonym jako „dobrobyt ludu”, posługiwał się w swojej doktrynie „trzech zasad ludu” Sun Jat-sen. Koncepcja ta, poprzez owe konotacje, jest równocześnie przywróceniem chińskiej pomocy etosu sprawiedliwego, socjalistycznego rozwoju społecznego. Zob. Liu Hongming, Luo Jianbo, Zhong-Fei Fazhan Hezuo. Lilun, Zhanlüe yu Zhengce Yanjiu [Chińsko-Afrykańska Współpraca Rozwojowa. Studia nad teorią, strategią i polityką], Beijing 2011, s. 243. 
narodów Afryki w ich walce $\mathrm{z}$ imperializmem i kolonializmem ${ }^{194}$. Chiny kultywowały swój wizerunek państwa przyjacielskiego, szanującego lokalne tradycje i poszukiwania własnych ścieżek modernizacyjnych. W czasie tournée dyplomatycznego po niepodległych państwach Afryki w 1963 r. Zhou Enlai przedstawił „pięć zasad" rozwoju stosunków ChRL z państwami kontynentu i „osiem zasad” pomocy gospodarczej i technicznej195. W skrócie odwoływały się one do „pięciu zasad pokojowego współistnienia” i zawierały deklarację Chin, że powstrzymają się od wszelkich ingerencji w wewnętrzne sprawy Afryki, oferując bezinteresowną i przyjacielską pomoc $\mathrm{w}$ duchu internacjonalizmu i braterstwa ludów wyrywających się spod dominacji imperializmu i kolonializmu. Ta retoryka jest obecna $\mathrm{w}$ chińskich relacjach z Afryką do dziś, a jej praktycznym przejawem może być angażowanie się Pekinu w projekty rozwojowe na kontynencie, w które nie angażują się państwa Zachodu z obawy o zbyt trudne warunki panujące na miejscu czy też współdzielenie przez chińskich robotników i specjalistów trudnych warunków życia w Afryce wraz z ich gospodarzami ${ }^{196}$. Pragnienie utrzymania wizerunku Chin jako bliskiego sojusznika i przyjaciela Afryki utrzymało się po rozpoczęciu reform gospodarczych w $1978 \mathrm{r}$. Wymowę podobną do deklaracji Zhou miały „cztery zasady” stosunków i współpracy chińsko-afrykańskiej przedstawione w 1982 r., w czasie wizyty w Afryce premiera Zhao Ziyanga: „równość, bilateralizm, efektywność, wspólny rozwój”"197. W 1996 r. Jiang Zemin złożył Afryce kolejną ,pięciopunktową propozycję”, obejmującą „trwałą przyjaźń, suwerenną równość, nieinterwencję, wzajemnie korzystny rozwój i współpracę międzynarodową" 198 . Wierność Chin ,pięciu zasadom”, jako podstawie współpracy, pokoju, stabilności i wspólnego dobrobytu całego świata, władze ChRL zadeklarowały również w preambule do „Afrykańskiej Polityki Chin”. Stwierdza się tam, że „kontynent afrykański, na którym znajduje się największa liczba państw rozwijających się, jest ważną siłą dla światowego pokoju i rozwoju. Tradycyjnie przyjazne stosunki chińsko-afrykańskie stoją przed nowymi szansami w nowych okolicznościach"199. Definiując te stosunki, autorzy dokumentu stwierdzają,

194 P. Snow, The Star Raft. China's Encounter with Africa, New York 1988, s. 72-73.

195 Luo Jianbo, Zhang Xiaomin, China's African Policy and its Soft Power, AntePodium 2009, s. 2.

196 Na przykład: „Li Xiaohai, dyrektor jednej z wielu chińskich elektrowni w Afryce sam cierpiał na malarię, i twierdzi, że ludzie z Zachodu nie zgodziliby się na warunki, które znosi wielu jego pracowników”. A. Moody, Zhong Nan, Track Record. As China-Africa Trade and Investment Soar, Many Leaders See Relationship as Central to Continent, „China Daily. European Weekly”, 29.06-5.07.2012.

197 Li Anshan, China's New Policy toward Africa, [w:] China into Africa..., s. 21.

198 President Jiang Zemin's Visit to Six African Countries, http://www.fmprc.gov.cn/eng/ziliao/3602/3604/t18035.htm [dostęp 8.02.2013].

199 China's African Policy... 
że „szczerość, równość i wzajemne korzyści, solidarność i wspólny rozwój są nadrzędnymi zasadami wymiany i współpracy chińsko-afrykańskiej”200.

Gwałtowny wzrost wymiany gospodarczej i obecności chińskiej na kontynencie spowodował jednak, że wielu jego mieszkańców zaczęło odczuwać faktyczne wpływy Chin na swoje życie i często oceniać je inaczej, niż wynikałoby to jedynie z chińskich deklaracji przyjaźni i braterstwa. Choć według badań Pew Research z 2007 r. zdecydowana większość Afrykanów pozytywnie postrzega gospodarczy wpływ Chin, to jednak w wielu krajach odsetek osób negatywnie oceniających wpływ wzrostu militarnej potęgi Chin jest znaczący; najwięcej w Tanzanii - 41\% (przy $41 \%$ ocen pozytywnych), RPA (39\%), Etiopii (38\%) i Ugandzie (28\%). W tych trzech ostatnich krajach Chiny są postrzegane bardziej negatywnie niż USA ${ }^{201}$. Jest to jedna z przyczyn, dla których Pekin intensyfikuje obecnie wysiłki na rzecz promocji swojego pozytywnego wizerunku, odwołując się do koncepcji soft power.

Jednym z tradycyjnych narzędzi tworzenia pozytywnego wizerunku ChRL w Afryce jest od lat 50. XX w. wykorzystywanie kontaktów międzyludzkich na różnych szczeblach. Jedną $\mathrm{z}$ trwałych tradycji tego nurtu jest powierzanie funkcji reprezentacyjnych i praktycznych w kontaktach z muzułmańskimi społecznościami i krajami Afryki muzułmanom chińskim, zarówno Hui, jak i z innych grup etnicznych. Już w czasie konferencji w Bandungu w 1955 r., gdzie doszło do pierwszych oficjalnych rozmów Zhou Enlai'a z egipskim prezydentem Nasserem, rolę tłumacza pełnił znany szanghajski imam Da Pusheng ${ }^{202}$. W latach 60. liczne delegacje z krajów afrykańskich, które odzyskały niepodległość, zdominowanych przez wyznawców islamu, przyjmowane były przy współudziale Muzułmańskiego Związku Religijnego w ChRL ${ }^{203}$. W „polityce propagandy historycznej” chętnie jest wykorzystywana również rola muzułmańskiego eunucha z czasów dynastii Ming - admirała Zheng He w nawiązywaniu „przyjaznych” kontaktów z Afryką. Zheng i jego wyprawy, m.in. do dzisiejszej Somalii, są w niej ukazywane jako misje przyjaźni i wzajemnych korzyści, tak jak współczesne wizyty dyplomatyczne przywódców ChRL, i przeciwstawiane „łupieżczym i kolonialnym podbojom Zachodu"204. Obecnie przewodniczącym Ludowego Towarzystwa

200 Ibidem, cz. II.

201 Pew Global Attitudes Project. 2007. Pew Global Attitudes Project, s. 41, http://pewglobal.org/reports/pdf/256.pdf [dostęp 8.02.2013]. Najnowsze dane Pew informują jedynie o odbiorze Chin w Kenii, gdzie osób pozytywnie oceniających ChRL jest $71 \%$ przy 21\% negatywnych. Pew Global Attitudes Project Spring 2011 Topline. Najpełniejszym opracowaniem afrykańskiego odbioru Chin i chińskiej obecności na kontynencie jest: B. Sautman, Yan Hairong, African Perspectives on China-Africa Links...

202 W. Cieciura. Muzułmanie chińscy wobec nowoczesności. Między radykalizmem i chińskim nacjonalizmem 1892-1957, praca doktorska, Łódź 2010.

203 P. Snow, The Star Raft..., s. 105-106.

204 Patrz np. Li Xinfeng, Zheng He Xia Xiyang yu Dangdai Zhongguo dui Feizhou Zhengce Bijiao [Porównanie wypraw Zheng He na Ocean Zachodni ze współczesną polityką Chin wobec Afryki], „Xiya Feizhou” [Zachodnia Azja i Afryka] 2010, no. 10, s. 50-57. 
Przyjaźni Chińsko-Afrykańskiej (Zhongguo Feizhou Renmin Youhao Xiehui), powołanego w 1960 r., jest Ujgur Abdul'ahat Abdulrixit, były przewodniczący rządu ludowego Xinjiangu i wiceprzewodniczący Ludowej Politycznej Konferencji Konsultatywnej. Aktywnie reprezentuje on ChRL w kontaktach z państwami Afryki, spotykając się z czołowymi politykami i przedstawicielami organizacji społecznych kontynentu ${ }^{205}$.

Ważnym elementem „wymiaru ludzkiego" tradycyjnej polityki wizerunkowej ChRL w Afryce jest „dyplomacja zdrowotna” - wysyłanie od 1964 r. zespołów medycznych do państw Afryki ${ }^{206}$. W sumie Chiny wysłały na kontynent od tamtego czasu przeszło 15 tys. lekarzy, oferując najuboższym krajom afrykańskim darmową pomoc medyczną w zwalczaniu malarii, chorób tropikalnych oraz HIV/AIDS. Działania zespołów medycznych koordynowane są przez poszczególne prowincje w ramach ich struktur służby zdrowia. Praktyka wysyłania lekarzy do Afryki jest jednak dla Chin kosztowna - zważywszy na bardzo słaby poziom usług medycznych na terenach wiejskich i ubogich w samych Chinach. Jej rola w budowie pozytywnego wizerunku ChRL w Afryce jest jednak tak duża, że Pekin kontynuuje wysyłanie zespołów. W lipcu 2012 r., w czasie szczytu FOCAC, Hu Jintao zadeklarował, że Chiny wyślą do Afryki 1500 lekarzy i będą kontynuować program darmowego leczenia chorych na kataraktęe ${ }^{207}$.

Jak wskazują niektórzy badacze, charakterystyka systemu politycznego ChRL i preferowanie przez nią państwowych kanałów komunikacji i prowadzenia działań dyplomatycznych powoduje, że chiński potencjał soft power w klasycznym ujęciu zachodnim jest mocno ograniczony. Wynika to m.in. z faktu, że nieufność, $\mathrm{z}$ jaką Chiny patrzą na prywatne środki przekazu, powoduje, iż ich atrakcyjność jest dla odbiorców ograniczona, a większość działań oficjalnych mediów chińskich odbierana jest jako propaganda, nie zwiększając atrakcyjności „chińskiego stylu życia"208. Dodatkowo, w ujęciu chińskim soft power bywa postrzegana jako składająca się z wszystkich elementów chińskiej polityki poza militarnymi środkami przymusu ${ }^{209}$. Uczeni chińscy postrzegają źródła soft power Chin w ich modelu rozwojowym, polityce zagranicznej, instytucjach i tzw. agenda setting, które spotykają się w dyplomacji kulturalnej, dyplomacji multilateralnej i programach pomocy zagranicznejeje. Inne chińskie ujęcie soft power dodaje do tych elementów kulturę, organizacje międzynarodowe i wyspecjalizowane media ${ }^{211}$.

205 http://www.capfa.org.cn/cn/about.asp?id=240 [dostęp 2.02.2013].

206 D. Thompson, China's Soft Power in Africa: From the „Beijing Consensus” to Health Diplomacy, „China Brief” 2005, vol. 5, issue 21.

207 Open Up New Prospects...

208 Ł. Fijałkowski, China's ,,Soft Power” in Africa?, ,Journal of Contemporary African Studies" 2011, vol. 29, no. 2, s. 225.

209 Ibidem.

210 Ibidem.

211 Hu Nan, Zhongguo dui Feizhou Ruanshili Yanjiu: Zhanlüe Fenxi yu Zhengce Jianyi [Badania nad chińskim soft power w Afryce: analiza strategii i sugestie polityczne], „Changchunshi 
Obecnie wskazuje się, że potencjalnie najbardziej nośnym tematem, do którego mogą odwoływać się Chiny w projekcji swojej soft power, jest chiński model rozwojowy, kładący nacisk na wytwarzanie wzrostu gospodarczego w drodze większej ekonomicznej integracji państw rozwijających się, bez konieczności wprowadzania daleko idących reform politycznych i gospodarczych, poza systemem budowanym przez Zachód w oparciu o międzynarodowe instytucje finansowe. W ujęciu tym większą rolę pełni państwo, jako główny decydent w kwestiach kierunków rozwoju gospodarczego, wykorzystujące przedsiębiorstwa państwowe i unikające gwałtownych kroków gospodarczych, takich jak postulowana w latach 90 XX w., w ramach konsensusu waszyngtońskiego, daleko idąca liberalizacja i „terapia szokowa”. Model ten, nazwany w 2004 r. przez Joshuę Ramo „konsensusem pekińskim”, jest często przywoływany w dyskusjach o atrakcyjności chińskich rozwiązań dla państw dawnego trzeciego świata. Choć władze ChRL oficjalnie odżegnują się od promowania jakiegokolwiek modelu rozwojowego, to artykuł Ramo został przetłumaczony szybko na chiński i rozkolportowany wśród 5 tys. członków władz, a czołowy teoretyk „,socjalistycznej gospodarki rynkowej” jako modelu globalnego Cheng Enfu pochwalił „naukowość koncepcji teoretycznych i praktyczną wyższość” koncepcji „,konsensusu pekińskiego” nad „konsensusem waszyngtońskim”212. Badacze dostrzegają przy tym wysiłki Chin na rzecz promocji własnych doświadczeń i rozwiązań wśród afrykańskich elit, poprzez zachęcanie afrykańskich partnerów handlowych do rozwijania swoich gospodarek za pomocą handlu i inwestycji w infrastrukturę i instytucje społeczne ${ }^{213}$. Szczególnym przykładem wykorzystania chińskich doświadczeń gospodarczych dla chińskiego soft power w Afryce może być tworzenie „stref współpracy gospodarczej i handlowej", zapowiedziane w czasie szczytu pekińskiego w $2006 \mathrm{r}$. W 2011 r. istniało już siedem takich stref: w Zambii, Egipcie, dwie w Nigerii, na Mauritiusie, w Etiopii i Algierii, rozwijanych przez korporacje chińskie jako swoisty odpowiednik specjalnych stref ekonomicznych w Chinach, dzięki którym ChRL dokonała cudu gospodarczego ${ }^{214}$.

W artykule opublikowanym przez Szkołę Partyjną w Changchunie, stolicy prowincji Jilin, która utrzymuje ożywione kontakty z państwami Afryki, jako pierwsze narzędzie soft power wymienia się kompleks narzędzi kulturowych ${ }^{215}$. Należy do nich zaliczyć m.in. kształcenie przyszłych afrykańskich elit w Chinach. Chiny już od lat 50. XX w. oferują stypendia dla afrykańskich studentów, a obietnica utrzymania tej praktyki została wpisana m.in. do „Afrykańskiej Polityki

Weidangxiao Xuebao" [Biuletyn Naukowy Szkoły Komitetu Miejskiego Partii w Changchunie], kwiecień 2011.

212 B. Sautman, Yan Hairong, Friends and Interests..., s. 84.

213 D. Thompson, China's Soft Power in Africa...

214 D. Brautigam, Tang Xiaoyang, African Shenzhen: China's Special Economic Zones in Afri$c a$, ,The Journal of Modern African Studies”, 2011, vol. 49, issue 01, s. 30.

215 Hu Nan, Zhongguo dui Feizhou Ruanshili... 
Chin”. Według szacunków profesora Li Baopinga do 2006 r. ok. 18 tys. afrykańskich studentów otrzymało stypendia rządowe do Chin ${ }^{216}$. W ,pekińskim planie działań” ze szczytu w 2006 r. znalazła się obietnica strony chińskiej zwiększenia liczby stypendiów rządu chińskiego dla studentów afrykańskich na chińskich uczelniach z 2000 rocznie do 4000 do roku 2009217. Adams Bodomo z Uniwersytetu w Hongkongu, badacz afrykańskich studentów w Chinach, ustalił, że władze chińskie zrealizowały tę obietnicę, dzięki czemu w latach 2007-2009 w Chinach studiowało ok. 12 tys. studentów z Afryki, w zdecydowanej większości na kierunkach ścisłych i inżynierskich ${ }^{218}$. Według oficjalnych chińskich statystyk w $2011 \mathrm{r}$. na chińskich uczelniach studiowało 20744 studentów z Afryki, co stanowiło $7,09 \%$ wszystkich studentów zagranicznych ${ }^{219}$. W czasie ostatniego szczytu ministerialnego FOCAC w Pekinie w lipcu 2012 r. prezydent Hu Jintao zadeklarował, że władze chińskie zwiększą liczbę stypendiów dla studentów z Afryki do 18 tys. oraz w ramach ,programu afrykańskich talentów” wyszkolą 30 tys. specjalistów w różnych dziedzinach w Afryce, a także zbudują w państwach afrykańskich sieć centrów szkoleniowych w zakresie kultury i umiejętności zawodowych ${ }^{220}$.

Ważnym narzędziem chińskiego soft power, oprócz fundowania stypendiów dla afrykańskich studentów, stała się również działalność Instytutów Konfucjusza - uczących języka chińskiego i promujących chińską kulturę na kontynencie. Zapowiedź ich tworzenia znalazła się w ,pekińskim planie działań” z 2006 r., ale pierwszy instytut otworzono już w 2005 r. przy Uniwersytecie w Nairobi ${ }^{221}$. Obecnie w Afryce działają 22 IK w 17 krajach - 4 w RPA, 2 w Kenii, Egipcie i Nigerii oraz po jednym w Botswanie, Zimbabwe, Kamerunie, Liberii, Ruandzie, na Madagaskarze, w Sudanie, Maroku, Togo, Beninie, Etiopii i Zambii ${ }^{222}$. Przy braku w Afryce ośrodków studiów chińskich, Instytuty Konfucjusza pełnią funkcje ich zarodników i tym samym w znaczącym stopniu wzbogacają miejscowe życie akademickie i intelektualne ${ }^{223}$. Oczywiście w takiej sytuacji istnieje możli-

216 D. Brautigam, How Many Africans Are Studying in China?, 28.09.2010, http://www.chinaafricarealstory.com/2010/09/how-many-africans-are-studying-in-china.html [dostęp 3.02.2013].

217 Pekiński plan działań na lata 2007-2009, http://www.focac.org/eng/ltda/dscbzjhy/ DOC32009/t280369.htm [dostęp 3.02.2013].

218 Adams Bodomo, Fresh Faces for Future Africa-China Relations: A Note on the Experiences of Newly-Arrived African Students in China on FOCAC Funds. Paper for the Symposium on Reviews and Perspectives of Afro-Chinese Relations organized by the Institute of African and West Asian Studies/Chinese Academy of Social Sciences, 13.10.2009, Beijing, China. Według szacunków autora dodatkowe 8 tys. studentów studiowało za własne środki.

219 Statistics of International Students in China in 2011, 29.02.2012, http://www.csc.edu.cn/ Laihua/newsdetailen.aspx?cid=122\&id=1399 [dostęp 3.02.2013].

220 Open Up New Prospects...

221 http://english.hanban.org/confuciousinstitutes/node_10908.htm [dostęp 3.02.2013].

222 Dane ze strony Hanbanu: http://english.hanban.org/node_10971.htm [dostęp 3.02.2013].

${ }^{223}$ M. Vermaak, What Should African Confucius Institutes do?, „The China Monitor”, issue 47, January 2010 [Stellenbosch University Center for Chinese Studies]. 
wość, że przyszłe afrykańskie studia chińskie będą się cechować tendencjami do podzielania wielu poglądów i przekonań pochodzących z oficjalnych kręgów akademickich ChRL. Pomimo tego Hanban, organizacja zwierzchnia dla Instytutów Konfucjusza, opowiedziała się w 2009 r. za dostosowywaniem poszczególnych jednostek do miejscowych warunków, odchodząc od ujednoliconego modelu ich funkcjonowania. Jak podkreśla jeden $\mathrm{z}$ afrykańskich obserwatorów prac IK na kontynencie, w obliczu słabo rozwiniętej miejscowej edukacji wyższej instytuty mają szansę odgrywać tu ważniejszą rolę edukacyjną niż w Europie, co znajduje obecnie odzwierciedlenie w fakcie, iż rozważane jest wprowadzenie w afrykańskich IK programów studiów wyższych zakończonych zdobyciem dyplomu ${ }^{224}$.

Faktyczne wpływy IK na postrzeganie Chin w Afryce są jednak obecnie trudne do oceny. Jak zauważa autor publikacji zamieszczonej w biuletynie szkoły partyjnej w Changchunie, ,,współczesna chińska kultura popularna nie może równać się z wpływami popkulturowymi państw zachodnich - USA, Europy, a nawet Indii i Korei Południowej. Tradycyjna kultura chińska, choć niezwykle stara i wyrafinowana, jest jednak bardzo trudna w promocji. Dla początkujących uczących się w Afryce tangowska i songowska poezja jest zbyt trudna do zrozumienia. To powoduje, że promocja kultury chińskiej stoi przed ogromnymi trudnościami, a chińska soft power ma przed sobą poważne wyzwania"225. Autor zauważa również problem tkwiący w całkowitej rządowej kontroli nad zasobami soft power i postuluje „dalszy ich rozwój” w kierunku większego nacisku na bezpośrednie kontakty międzyludzkie. Trudno jednak wyobrazić sobie, jak mogłoby do tego dojść poza kontrolą władz chińskich, skoro nie chcą z niej zrezygnować. Paradoksem jest już samo wezwanie do takich zmian zamieszczone w biuletynie politycznej szkoły partyjnej.

Tworzenie instytutów, w których afrykańska młodzież ma szansę rozpocząć naukę języka chińskiego i poznawanie kultury Chin - w wersji aprobowanej przez władze ChRL - jest zatem elementem strategii dyplomacji publicznej Pekinu. Ma ona zasadniczo pięć celów: upublicznianie stanowiska władz, kształtowanie pożądanego obrazu Chin, wydawanie dementi w przypadkach „krzywdzących zagranicznych doniesień o Chinach", poprawianie międzynarodowej atmosfery wokół Chin i wywieranie wpływu na decyzje polityczne obcych państw ${ }^{226}$. Istotną rolę pełnią tutaj kontrolowane przez państwo chińskie media, które wcześniej działały w niezbyt wyrafinowany sposób, odwołując się do archaicznych działań propagandowych. Choć ośrodki informacyjne ChRL, takie jak agencja prasowa Xinhua, obecnie działają w bardziej wyrafinowany sposób, nadal są bardzo ściśle kontrolowane przez władze partyjne ${ }^{227}$. Bardziej profesjonalne podejście do

224 Ibidem.

225 Hu Nan, Zhongguo dui Feizhou Ruanshili...

226 Rumi Aoyama, za J. Kurlantzick, Charm Offensive: How China's Soft Power Is Transforming the Word, A New Republic Book, New York 2007, s. 77.

227 Ibidem, s. 63. 
kwestii prezentacji oficjalnej wizji świata przez media z ChRL powoduje jednak, że obecnie są one często cytowane i uznawane za wiarygodne, szczególnie poza światem zachodnim ${ }^{228}$.

Lepiej zaprojektowane strony internetowe (choć pod tym względem nadal wiele zostaje do zrobienia) i lepiej sformatowane czasopisma oraz programy radiowe i telewizyjne pomagają ChRL promować swoje postrzeganie świata. $\mathrm{Na}$ kontynencie afrykańskim nasilona ofensywa medialna Chin znalazła odbicie w stworzeniu afrykańskiej redakcji telewizji chińskiej CCTV, z centrum produkcyjnym w Nairobi, które rozpoczęło pracę 11 stycznia 2012 r. ${ }^{229} \mathrm{~W}$ grudniu tego samego roku powołano również miejscową edycję gazety "China Daily”, w formie tygodnika „China Daily Africa Weekly”230. Choć jest zbyt wcześnie, by oceniać efekty działalności tych dwóch ośrodków, to widać wagę, jaką Chiny do niej przykładają. Choć CCTV Africa produkuje obecnie tylko godzinę anglojęzycznych programów dziennie (wiadomości, talk show „Talk Africa” i reportaż „Faces of Africa”), resztę ramówki wypełniając materiałami stacji-matki, udział własnych produkcji będzie rosnąć. Programy produkcji chińskiej emitowane w Afryce i afrykańskie nagrywane przez CCTV mają w zamierzeniu decydentów zbliżać do siebie Chińczyków i Afrykańczyków. Jako prezenterów stacji w Nairobi zatrudniono dziennikarzy afrykańskich, w tym tak doświadczonych jak Beatrice Marshall231, nadając przekazowi medialnemu z Chin „znajomą twarz”.

\section{Wojskowe narzędzia polityki ChRL wobec Afryki}

Współczesne chińskie zaangażowanie militarne Chin w Afryce przybiera trzy formy: handlu bronią, udziału w misjach pokojowych ONZ oraz w formie odpowiedzi na przypadki porwań chińskich obywateli i ataków na chińskie instalacje $^{232}$. Chińska Republika Ludowa posiada długą tradycję związków militarnych z państwami kontynentu afrykańskiego. W okresie dekolonizacji Chiny, mimo deklarowanej zasady nieingerencji w wewnętrzne sprawy innych państw, wspierały liczne ugrupowania walczące o niepodległość Afryki. Wynikało to z przekonania, że kraje skolonizowane nie rządzą się samodzielnie, a poparcie dla ich dążeń narodowowyzwoleńczych jest internacjonalistycznym obowiązkiem Chin ${ }^{233}$.

228 Ibidem, s. 64.

229 About CCTV Africa, http://cctv.cntv.cn/lm/cctvafrica/01/index.shtml [dostęp 5.02.2013].

230 China Daily Launches Africa Weekly Edition, 14.12.2012, http:/www.chinadaily.com.cn/ cndy/2012-12/14/content_16016342.htm [dostęp 5.02.2013].

231 http://english.cntv.cn/program/talkafrica/20120223/107973.shtml [dostęp 5.02.2013].

232 Chuka Enuka, China's Military Presence in Africa: Implications for Continental Instability, ,Sacha Journal of Policy and Strategic Studies” 2011, vol. 1, no. 1, s. 68-81.

233 Zob. S. Hess, R. Aidoo, Beyond the Rhetoric: Noninterference in China's African Policy, „Asian and African Studies” 2010, vol. 9, s. 356-383. 
W 1958 r. Pekin uznał algierski Front Wyzwolenia Narodowego i rozpoczął dostawy lekkiej broni dla jego bojowników ${ }^{234}$. W kolejnych dekadach wsparcie Chin Ludowych dla afrykańskich ruchów wyzwoleńczych nie słabło, a Pekin wspierał partyzantów w Gwinei-Bissau, Mozambiku, Rodezji, Kongo i w innych krajach. Chińscy instruktorzy szkolili afrykańskich bojowników z kolonii portugalskich w obozach na terytorium Ghany i Tanzanii oraz w akademii wojskowej w Nankinie $^{235}$. Wieloletnie doświadczenia żołnierzy Chińskiej Armii Ludowo-Wyzwoleńczej w walkach partyzanckich przekładały się na sposób szkolenia afrykańskich bojowników. Pisma Mao Zedonga o taktyce i metodach walki chłopskiej były uważane przez Chińczyków za szczególnie przydatne w wojnach toczących się na kontynencie afrykańskim ${ }^{236}$. Nasilenie konfrontacji ideologicznej ze Związkiem Radzieckim spowodowało, że w konfliktach wewnętrznych w nowych państwach Afryki z czasem Pekin wspierał ugrupowania zbrojne jedynie na podstawie tego, że nie otrzymywały go z Moskwy 237 .

Skomplikowana sytuacja polityczna tych konfliktów, zaangażowanie w nie zarówno ZSRR, jak i jego sojuszników oraz państw Zachodu powodowały, że wsparcie chińskie często trafiało do kilku stron. Szczególnie widoczne było to w czasie wojny domowej w Angoli, gdzie ChRL na różnych etapach wspierała MPLA, UNITA i FNLA, by ostatecznie wesprzeć koalicję FNLA-UNITA, popieraną przez USA i apartheidowską RPA, przeciwko wspieranej przez ZSRR i Kubę MPLA ${ }^{238}$. Zaangażowanie w ten konflikt skończyło się dla ChRL prestiżową porażką wraz ze zwycięstwem MPLA i przejęciem przez nią władzy. Podobną porażkę poniosła ona również w Kongo, gdzie wspierane przez nią ugrupowania przegrały z wojskami rządowymi. Pomimo tych niepowodzeń ChRL była później w stanie nawiązać bliskie związki zarówno z Zairem Mobutu Sese Seko, jak i z niepodległą Angolą, dziś jednym z najważniejszych partnerów Chin na kontynencie.

Wraz z zaangażowaniem politycznym i militarnym ChRL w Afryce Pekin zaczął budować swoją pozycję ważnego eksportera uzbrojenia na kontynent. W latach 60 . ChRL była szóstym dostawcą broni do Afryki, z czego $83 \%$ chińskiego eksportu trafiało do Tanzanii ${ }^{239}$. Pod przywództwem Juliusa Nyerere kraj ten stał się najważniejszym sojusznikiem Chin w Afryce i największym odbiorcą chińskiej broni. ChRL dostarczyła wówczas do Tanzanii kilkadziesiąt czołgów, kilkanaście okrętów, 12 myśliwców Mig-17 oraz wybudowała bazę tanzańskiej

${ }_{234}$ D.H. Shinn, Military and Security Relations: China, Africa, and the Rest of the World, [w:] China into Africa. Trade, Aid..., s. 156.

235 P. Snow, The Star Raft..., s. 77-78.

236 Ibidem.

237 D.H. Shinn, Military and Security Relations..., s. 156.

238 S. Hess, R. Aidoo, Beyond the Rhetoric..., s. 363.

239 D.H. Shinn, Military and Security Relations..., s. 158. 
marynarki wojennej, lotnisko wojskowe i prowadziła szkolenia dla wszystkich rodzajów sił zbrojnych ${ }^{240}$. Przez całe lata 60 . i 70. wysyłała do Afryki broń, w tym myśliwce, łodzie patrolowe, broń lekką itp., stając się ważnym dostawcą uzbrojenia, choć znacznie mniej istotnym niż państwa Zachodu i ZSRR ${ }^{241}$. Od $1978 \mathrm{r}$. ChRL uzbrajała Somalię przeciwko wspieranej przez ZSRR Etiopii ${ }^{242}$.

W latach 80., po rozpoczęciu reform gospodarczych, ChRL w polityce eksportu uzbrojenia skoncentrowała się na krajach Azji, ograniczając dostawy do Afryki. Niemniej były one kontynuowane w ograniczonym zakresie, m.in. do Egiptu, któremu sprzedano sześć łodzi podwodnych, 80 myśliwców F-7, 55 czołgów i kilkadziesiąt rakiet ziemia-ziemia ${ }^{243}$. W dekadzie lat 80. rozpoczęła się intensywna współpraca w dziedzinie sprzedaży sprzętu i szkolenia wojska między ChRL i Zimbabwe, do dziś jednym z ważnych sojuszników Chin w Afryce, któremu sprzedano 67 myśliwców typów F-7 i F-6 oraz 44 czołgów typów T-59 i T-60; instruktorzy chińscy zainicjowali też programy szkolenia pilotów zimbabweńskich sił powietrznych ${ }^{244}$. Pod koniec tej dekady rozpoczęła się również sprzedaż chińskiej broni do Sudanu. Należy jednak podkreślić, że oferowane wówczas przez Chiny uzbrojenie było stosunkowo niskiej jakości i w większości składało się ze sprzętu będącego chińskimi wersjami broni produkcji radzieckiej.

W latach 90. rola Chin jako dostawcy uzbrojenia i partnera militarnego państw afrykańskich stała się źródłem nowych kontrowersji, wraz ze wzrostem pozycji politycznej i gospodarczej kraju na arenie międzynarodowej. Obiektem szczególnej krytyki stały się związki wojskowe z potępianymi przez społeczność międzynarodową krajami autorytarnymi, takimi jak Sudan i Zimbabwe, dla których Chiny okazały się jedynymi dostępnymi dostawcami uzbrojenia. Departament Stanu USA szacował, że w dekadzie 1989-1999 ChRL sprzedała na kontynent afrykański broń o wartości 1,3 mld USD, z czego $200 \mathrm{mln}$ do Afryki północnej, $600 \mathrm{mln}$ do Afryki centralnej i $500 \mathrm{mln}$ do Afryki południowej ${ }^{245}$. Polityka sprzedaży broni do Afryki w tym okresie ostatecznie została odseparowana od kwestii ideologicznych, i tak np. w czasie wojny etiopsko-erytrejskiej w latach 1998-2000 ChRL sprzedawała broń obu stronom konfliktu ${ }^{246}$. W dekadzie lat 90. nastąpiła intensyfikacja kontaktów dyplomatycznych na szczeblu wojskowym między ChRL i państwami Afryki, ze wzrostem liczby afrykańskich attachatów militarnych w Pekinie do 13, a chińskich w Afryce do 2006 r. do co najmniej $14^{247}$.

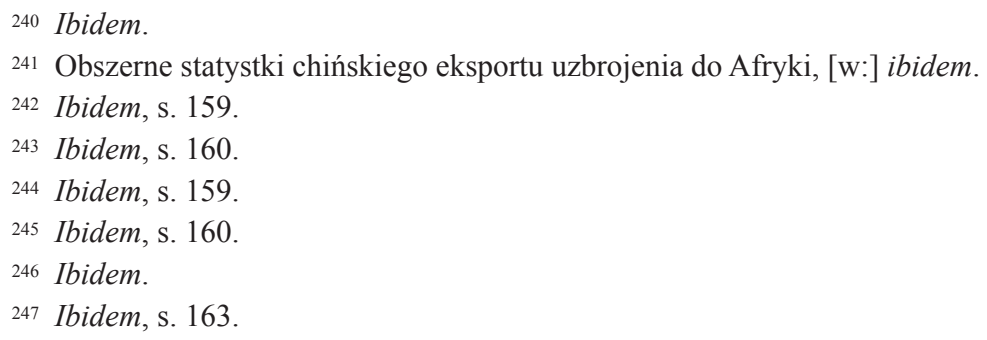


Obecnie jednym z najbardziej kontrowersyjnych aspektów chińskiej obecności w Afryce jest rosnąca sprzedaż broni, w szczególności lekkiej, a co za tym idzie - najłatwiej dostępnej, dla państw kontynentu, która ma być czynnikiem destabilizującym i sprzyjającym łamaniu praw człowieka ${ }^{248}$. Latem 2012 r. „Washington Post" opublikował artykuł, w którym Chiny zostały przedstawione jako kraj „zalewający Afrykę Subsaharyjską bronią”, która następnie trafia do regionów ogarniętych krwawymi walkami, w krajach takich jak Kongo, Wybrzeże Kości Słoniowej, Sudan i Somalia ${ }^{249}$. Autor zarzucał również dyplomatom chińskim niepotrzebne utrudnianie śledztw prowadzonych przez ONZ, łamanie embarga (bez stwierdzenia, że jest to działalność celowa) na dostawy broni m.in. do Libii i Sudanu, przyznając jednak, że w wielu kwestiach strona chińska zmienia swoje postępowanie i wprowadza większą przejrzystość. Zarzuty podniesione przez cytowanych w artykule pracowników ONZ dotyczą przede wszystkim chińskiej sprzedaży do Afryki broni lekkiej i małej, często za pośrednictwem firm zbrojeniowych czy pośredników handlowych, bez zawierania kontraktów międzyrządowych. Jak stwierdza się w omawianym tekście, rząd chiński nie kontroluje do końca owych firm, które, choć są w większości własnością państwa, kierują się przede wszystkim chęcią zysku, bez uwzględniania kwestii wizerunku Chin na arenie międzynarodowej. Opór strony chińskiej przed wprowadzeniem większej przejrzystości w handlu bronią w Afryce, w tym np. w Sudanie, niepotrzebnie zwraca uwagę świata na Pekin, podczas gdy najbardziej śmiercionośną, i dużo droższą, broń, m.in. śmigłowce bojowe, reżimowi w Chartumie sprzedają takie państwa jak Rosja, Białoruś i Ukraina ${ }^{250}$.

Wśród badaczy nie ma zgody co do rzeczywistych rozmiarów chińskiego eksportu uzbrojenia do Afryki, ani co do tego, czy faktycznie jest on czynnikiem destabilizującym i wspierającym rządy autorytarne. Ponieważ Chiny nie publikują oficjalnych danych dotyczących sprzedaży broni, wszystkie podawane wielkości mają charakter orientacyjny, co sprzyja złej atmosferze wokół tej kwestii. Specjaliści z Norweskiego Uniwersytetu Nauki i Technologii w opublikowanej analizie wskazują, że paradoksalnie Chiny w swoim handlu bronią z państwami Afryki preferują kraje demokratyczne, takie jak Namibia i Zambia, podczas gdy Stany Zjednoczone sprzedają broń chętniej reżimom autorytarnym, takim jak Egipt (za czasów Mubaraka) i Maroko ${ }^{251}$. W oparciu o badania chińskiej sprzedaży

248 I. Taylor, Arms Sales to Africa: Beijing's Reputation at Risk, „China Brief” 2007, vol. 7, issue 7.

249 C. Lynch, China's Arms Exports Flooding Sub-Saharan Africa, „Washington Post”, 25.08.2012. Bardzo krytyczna ocena chińskiego zaangażowania w sprzedaż broni do stref konfliktów i wpływu na sytuację polityczną Afryki, przedstawiona przez afrykańskiego badacza odbywającego staż podoktorski na Uniwersytecie Jilin zob. Chuka Enuka, China's Military Presence in Africa...

250 Ibidem.

251 P. Midford, I. de Soysa, Enter the Dragon! An Empirical Analysis of Chinese versus US Arms Transfers to Autocrats and Violators of Human Rights, 1989-2006, http://stockholm.sgir.eu/ 
broni w Afryce, opracowane przez Sztokholmski Międzynarodowy Instytut Badań nad Pokojem (SIPRI), wykazali oni m.in., że w przypadku Sudanu, mającego być głównym odbiorcą broni z Chin w Afryce, w latach 2001-2008 największym dostawcą broni do tego kraju była Rosja, która sprzedała Chartumowi broń o wartości ponad pięciokrotnie większej niż Chiny ${ }^{252}$. Również Białoruś nie pozostaje daleko w tyle za Chinami, sprzedając Chartumowi uzbrojenie za $70 \%$ wartości chińskiego eksportu do Sudanu. W przypadku Zimbabwe badania wykazały, że faktycznie ChRL jest największym dostawcą broni, ale wbrew pojawiającym się zarzutom państw zachodnich, nie jedynym - niemal równie duże kontrakty z Harare zawierały Libia i Ukraina. Badacze konkludują, że rola Chin jako arsenału dla państw autorytarnych kontynentu afrykańskiego została wyolbrzymiona. Jednak krytycy ich podejścia wskazują, że opieranie się na danych SIPRI jest metodologicznie błędne, gdyż nie uwzględniają one zupełnie sprzedaży broni lekkiej, która stanowi największą część chińskiego eksportu do Afryki, i handel którą jest obecnie $\mathrm{w}$ fazie gwałtownego wzrostu ${ }^{253}$. Chiny bywają również oskarżane (choć doniesienia te są niepotwierdzone) o dostarczanie państwom takim jak Zimbabwe technologii kontroli Internetu i komunikacji elektronicznej254. Rządzone autorytarnie przez Roberta Mugabe Zimbabwe przyznało się również w 2004 r. do zakupu w Chinach 12 myśliwców i 100 pojazdów wojskowych ${ }^{255}$. Sam Mugabe w publicznym wystąpieniu w 2006 r. ostrzegał opozycję przed próbami buntu, grożąc, że „mamy wojskowych, którzy potrafią pociągnąć za spust [...] polityka patrzenia na wschód (tj. na Chiny) przysłużyła się siłom zbrojnym, które nie tylko otrzymały nowy sprzęt, ale również nauczyły się nowych strategii" ${ }^{256}$.

W kontekście chińsko-afrykańskiego handlu uzbrojeniem należy wspomnieć o wyjątkowym przypadku eksportu afrykańskiej broni do ChRL. Jedynym poważniejszym krajem sprzedającym uzbrojenie ChAL-W jest oczywiście RPA, posiadająca duży sektor zbrojeniowy, od której Chiny zakupiły bliżej nieokreślone ilości dział G-5 i G-6 oraz działa uniwersalne dla swojej marynarki wojennej257.

uploads/Midford\%20de\%20Soysa\%20AUG\%2022\%202010_final.pdf [dostęp 10.02.2013]. Artykuł opublikowano również: „International Studies Quarterly” 2012, vol. 56, issue 4.

${ }^{252}$ Ibidem. Chiny odpowiednio sprzedały w tym okresie broń o wartości $139 \mathrm{mln}$ TIV USD, przy 701 TIV mln USD Rosji. TIV - Trend Indicator Value jest systemem mierzenia międzynarodowych przepływów broni konwencjonalnej opracowanym przez SIPRI, opartym na znanych kosztach produkcji jednostki broni z określonego zakresu. Ma w założeniu reprezentować przepływ zasobów militarnych, a nie finansową wartość przepływu. Więcej zob. http://www.sipri.org/databases/armstransfers/background/explanations2_default [dostęp 12.02.2013].

253 D. Brautigam, 3.01.2011, http://www.chinaafricarealstory.com/2011/01/us-far-outstripschina-in-arms-sales-to.html [dostęp 10.02.2013].

${ }_{254}$ I. Taylor, Arms Sales to Africa ... zob też Freedom House, Freedom on the Net 2011, UNHCR, http://www.unhcr.org/refworld/pdfid/4dad51bd0.pdf [dostęp 20.01.2013].

255 I. Taylor, Arms Sales to Africa...

256 Ibidem.

257 D.H. Shinn, Military and Security Relations..., s. 170. 
Chiny sprzedają Afryce nie tylko konwencjonalne produkty swojego kompleksu militarnego. Najbardziej zaawansowanymi technologicznie elementami wymiany handlowej między Chinami i kontynentem stają się satelity produkcji chińskiej państwowej korporacji China Aerospace Science and Technology Corporation (Zhongguo Hangtian Keji Jituan Gongsi). Firma ta, powołana w 1999 r. w wyniku reform branży zbrojeniowej w ChRL, jest głównym dostawcą chińskiego programu kosmicznego i już w 2004 r. podpisała kontrakt z władzami Nigerii na zbudowanie i umieszczenie na orbicie pierwszego nigeryjskiego satelity komunikacyjnego NigComSat-1, za który Nigeria zapłaciła $340 \mathrm{mln}$ USD $^{258}$. Dla Chin był to pierwszy zagraniczny kontrakt na sprzedaż sprzętu kosmicznego. W $2007 \mathrm{r}$. ważący 5 ton satelita został wyniesiony na orbitę z centrum kosmicznego Xichang w Syczuanie przez rakietę nośną Długi Marsz 3B. Satelita okazał się jednak trudnym pierwszym doświadczeniem dla chińskiego przemysłu kosmicznego, źle przewidziane częstotliwości nadajnika nie sprawdziły się w czasie sezonu deszczowego w Nigerii ${ }^{259}$, a sam satelita 11 listopada 2008 r. uległ awarii zasilania, został zepchnięty na bezpieczną orbitę i wyłączony z eksploatacji260. W $2009 \mathrm{r}$. władze nigeryjskie podpisały kolejny kontrakt na następnego satelitę NigComSat$-1 \mathrm{R}$, który miał zastąpić zepsutą jednostkę. Strona chińska zdecydowała, że satelita zostanie zbudowany bez dodatkowych kosztów dla nigeryjskiego klienta ${ }^{261}$. Urządzenie zostało umieszczone na orbicie $\mathrm{z}$ tego samego centrum kosmicznego 20 grudnia 2011 i przekazane stronie nigeryjskiej 19 marca 2012 r. ${ }^{262}$ Jednym z jego zadań ma być utrzymanie bezpośredniej komunikacji między Nigerią i Chinami $^{263}$. W listopadzie 2012 r. władze chińskie i China Aerospace Science and Technology Corporation podpisały kolejny kontrakt na budowę i umieszczenie przed końcem 2015 r. kolejnego satelity dla państwa afrykańskiego - Kongo ${ }^{264}$.

Choć Afryka nie jest z punktu widzenia budowy chińskiego potencjału militarnego i geostrategicznego pierwszorzędnym teatrem działań, ChRL przykłada do współpracy wojskowej z państwami kontynentu istotną uwagę. W dokumencie „Afrykańska Polityka Chin” z 2006 r. znalazł się m.in. zapis o „promocji przez

258 Nigerian Satellite Fails in Space, 13.11.2008, http://news.bbc.co.uk/2/hi/africa/7726951. stm [dostęp 20.01.2013].

259 Ibidem.

260 Nigcomsat-1 Program,

http://www.cgwic.com/In-OrbitDelivery/CommunicationsSatellite/Program/NigComSat-1 . html [dostęp 30.01.2013].

261 Chinese Long March 3B/E Launches NigComSat-1R, 19.12.2011 http://www.nasaspaceflight.com/2011/12/chinese-long-march-3be-launches-nigcomsat-1r/ [dostęp 30.01.2013].

${ }_{262}$ China Hands Over NigComSat $1-R$ to Nigeria, http://news.xinhuanet.com/english/sci/ 2012-03/20/c_131476585.htm [dostęp 30.01.2013].

263 Chinese Long March 3B/E launches NigComSat-1R...

${ }^{264}$ China to Launch Communication Satellite for DR Congo, http://english.sina.com/business/2012/1117/527825.html [dostęp 30.01.2013]. 
Chiny wymiany wojskowej na wysokim szczeblu" oraz deklaracja kontynuowania „wojskowej wymiany technologicznej i współpracy”, a także obietnica kontynuacji szkolenia afrykańskiego personelu wojskowego i wsparcia dla zdolności obronnych Afryki. ChRL zadeklarowała również wówczas poparcie dla wysiłków Unii Afrykańskiej na rzecz rozwiązywania konfliktów regionalnych oraz zobowiązała się do wykorzystania swojego miejsca w Radzie Bezpieczeństwa ONZ do nakłaniania Rady do większej aktywności w zapobieganiu i rozwiązywaniu konfliktów na kontynencie. Zobowiązała się ponadto do kontynuacji zaangażowania w operacje pokojowe ONZ w Afryce ${ }^{265}$.

Chiński udział w strukturach ONZ odpowiedzialnych za misje pokojowe datuje się dopiero od $1988 \mathrm{r}$. We wcześniejszym okresie ChRL bardzo niechętnie patrzyła na to narzędzie wspólnoty międzynarodowej, uważając, że misje pokojowe są wykorzystywane do narzucania hegemonii mocarstw i są zamachem na uświęconą zasadę suwerenności i nieingerencji w wewnętrzne sprawy państw. Taka postawa przejawiała się m.in. w niepłaceniu aż do 1981 r. przez ChRL, jako jedynego stałego członka RB ONZ, składek na ten cel i stosowanego również później unikania głosowań w Radzie dotyczących tworzenia misji266. Niechęć do nich wynikała po części z historycznych doświadczeń ChRL w wojnie koreańskiej, w czasie której Chiny walczyły u swoich granic z siłami ONZ pod przewodnictwem USA. Angażowanie się ChRL w działania sił pokojowych ONZ w latach 90. XX w. wynikało z rosnącej pozycji kraju na arenie międzynarodowej i potrzeby zademonstrowania się światu jako odpowiedzialnego rozwijającego się mocarstwa oraz przełamania złego obrazu chińskich sił zbrojnych po wydarzeniach na placu Tian'anmen w 1989 r. ${ }^{267}$ Od lat 90 ChRL częściej głosuje w RB za formowaniem nowych misji pokojowych i obserwacyjnych w Afryce, choć nadal często zgłasza obiekcje w sytuacjach, gdy w jej ocenie nadany mandat może zbyt dalece ingerować w wewnętrzne sprawy kraju. Pomimo tego Chiny są obecnie ważnym źródłem członków misji pokojowych, a dwie trzecie z nich służy w Afry$\mathrm{ce}^{268}$. Fakt ten jest wykorzystywany przez władze w Pekinie w ich polityce soft power - budowy lepszego wizerunku państwa, jako oddanego sprawom pokoju i rozwiązywania konfliktów. Innym, bardziej praktycznym powodem, dla którego ChRL chętniej angażuje się obecnie w misje ONZ, jest jednak chęć zwiększenia obecności w strategicznie ważnych regionach Afryki, będących obecnie, lub potencjalnie, źródłem surowców ${ }^{269}$. Połączenie tych czynników było najprawdopodobniej przyczyną, dla której w 2008 r. prezydent ChRL Hu Jintao wywarł wy-

${ }_{265}$ China's African Policy, 4 Peace and Security (1) military cooperation, (2) Conflict settlement and peacekeeping operations.

${ }^{266}$ Wu Zhengyu, I. Taylor, From Refusal to Engagement: Chinese Contributions to Peacekeeping in Africa, ,Journal of Contemporary African Studies” 2011, vol. 29, no. 2, s. 137-154.

267 Ibidem.

268 Ibidem, s. 147.

269 Ibidem, s. 142. 
jątkowo mocny nacisk na przywództwo Sudanu, by podjęło współpracę z misją ONZ w Darfurze (UNAMID), której powołanie Chiny wsparły wcześniej w czasie głosowania nad rezolucją nr 1769 w ONZ ${ }^{270}$.

Według danych ONZ ze stycznia 2013 r. personel z ChRL bierze udział w sześciu misjach pokojowych z siedmiu na kontynencie afrykańskim (bez UNISFA - United Nations Interim Security Force for Abyei), łącznie 1520 osób, w tym 1495 żołnierzy. W sumie na misjach pokojowych ONZ przebywało w tym czasie 1838 żołnierzy ChRL, a więc w afrykańskich misjach ONZ uczestniczyło 81,3\% wszystkich wysłanych przez Pekin żołnierzy ${ }^{271}$. W tabeli 7.1 przedstawiono rozkład udziału chińskiego w poszczególnych misjach.

Tabela 7.1.

Udzial ChRL w misjach ONZ

\begin{tabular}{|c|c|c|c|c|c|c|}
\hline & $\begin{array}{c}\text { MINURSO } \\
\text { United Na- } \\
\text { tions Mission } \\
\text { for the } \\
\text { Referendum } \\
\text { in Western } \\
\text { Sahara }\end{array}$ & \begin{tabular}{|l} 
MONUSCO \\
United \\
Nations \\
Organization \\
Stabilization \\
Mission \\
in the Demo- \\
cratic Repu- \\
blic of the \\
Congo
\end{tabular} & $\begin{array}{l}\text { UNAMID } \\
\text { African } \\
\text { Union/Uni- } \\
\text { ted Nations } \\
\text { Hybrid } \\
\text { operation in } \\
\text { Darfur }\end{array}$ & $\begin{array}{c}\text { UNMIL } \\
\text { United Na- } \\
\text { tions Mission } \\
\text { in Liberia }\end{array}$ & \begin{tabular}{|c} 
UNMISS \\
United Na- \\
tions Mission \\
in the \\
Republic \\
of South \\
Sudan
\end{tabular} & $\begin{array}{l}\text { UNOCI } \\
\text { United Na- } \\
\text { tions Opera- } \\
\text { tion in Cotê } \\
\text { d'Ivoire }\end{array}$ \\
\hline Policjanci & - & - & - & 18 & 14 & - \\
\hline Eksperci & 10 & 15 & - & 2 & 3 & 6 \\
\hline Żołnierze & - & 218 & 323 & 564 & 347 & - \\
\hline W sumie & 10 & 233 & 323 & 584 & 364 & 6 \\
\hline Łącznie: & & & & & & 1520 \\
\hline
\end{tabular}

Źródło: https://www.un.org/en/peacekeeping/contributors/2013/jan13_5.pdf [dostęp 12.02.2013].

Jak widać, zdecydowaną większość chińskiego personelu misji ONZ stanowią żołnierze. Pełnią oni jednak wiele funkcji i w przypadku kontyngentów chińskich zdecydowaną większość z nich stanowią żołnierze wojsk inżynieryjnych, wojskowi lekarze i specjaliści ds. transportu ${ }^{272}$. I tak np. w Demokratycznej

270 Ibidem, s. 146.

271 https://www.un.org/en/peacekeeping/resources/statistics/contributors.shtml [dostęp 12.02.2013]. Łączna liczba chińskich uczestników misji pokojowych nie jest jednak duża - dla porównania, w tym samym czasie spośród sąsiadów Chin Mongolia wysłała na misje ONZ 938 żołnierzy, Indie 6851, Pakistan 8440, a Nepal 3804.

272 Chuka Enuka, China's Military Presence in Africa..., s. 73. 
Republice Kongo z ok. 200 żołnierzy chińskiego kontyngentu 175 pełniło funkcje inżynieryjne, a 40 stanowiło korpus medyczny ${ }^{273}$. Według wicedyrektora Biura ds. Misji Pokojowych w Ministerstwie Obrony ChRL chińscy członkowie misji pokojowych na całym świecie (choć zapewne udział proporcjonalny Afryki jest tu taki sam jak w przypadku całości tych misji) do 2004 r. zbudowali lub naprawili ponad 200 mostów, 7,5 tys. kilometrów dróg, lotnisk i urządzeń poboru wody oraz leczyli ponad 50 tys. pacjentów ${ }^{274}$.

Wraz ze wzrostem gospodarczej aktywności Chin w Afryce wzrasta również zapotrzebowanie na innego rodzaju obecność chińskich sił militarnych. Obywatele chińscy i chińskie inwestycje stawały się już ofiarami lokalnych niepokojów i konfliktów, m.in. w delcie Nigru w Nigerii, w Darfurze i Kordofanie w Sudanie, w Somalii i w najpoważniejszym incydencie w Etiopii, w kwietniu 2007 r., gdy członkowie Narodowego Frontu Wyzwolenia Ogadenu zaatakowali i zabili 9 chińskich pracowników Sinopecu ${ }^{275}$. W Kordofanie władze chińskie miały wysłać 400 członków swoich sił zbrojnych w cywilnych ubraniach do ochrony chińskich instalacji naftowych ${ }^{276}$ (nigdzie nie udało się zweryfikować tej informacji). W latach 2007-2012 doszło do co najmniej 14 przypadków porwań chińskich obywateli, ale Chiny nadal nie dysponują własnymi środkami mogącymi zaradzić tej sytuacji. Siły specjalne ChAL-W, choć dobrze wyszkolone, nie mają zdolności operacyjnych z dala od morza, a prywatne firmy ochroniarskie nie potrafią jeszcze działać w warunkach afrykańskich ${ }^{277}$. W tej sytuacji władze chińskie zmuszone są wywierać coraz większy nacisk na państwa-gospodarzy chińskich inwestycji, by zapewniły one Chińczykom bezpieczeństwo na swoim terytorium ${ }^{278}$. W ostatnich przypadkach przekaz strony chińskiej zdaje się wręcz sugerować, że pomoc rozwojowa jest uzależniona od zdolności miejscowych władz do zapewnienia bezpieczeństwa obywatelom ChRL. Tak było np. w Sudanie Południowym w 2012 r., któremu obiecano fundusze rozwojowe w wysokości 8 mld USD ${ }^{279}$. Chińskie siły specjalne działają jednak w obszarze Zatoki Adeńskiej, zapewniając bezpieczeństwo szlakom morskim i zwalczając piractwo w ramach akcji międzynarodowych ${ }^{280}$.

Ważnym aspektem chińskiej obecności militarnej w regionie Afryki jest zapewnienie bezpieczeństwa morskich szlaków handlowych, którymi przewożone są strategiczne surowce, jak ropa naftowa, z Afryki i Bliskiego Wschodu. Znaczenie basenu Oceanu Indyjskiego dla bezpieczeństwa strategicznego Chin rośnie

273 Ibidem.
274 Ibidem.
${ }_{275}$ D.H. Shinn, Military and Security Relations..., s. 179.
276 Chuka Enuka, China's Military Presence in Africa..., s. 74.
277 D. Houpt, Assessing China's Response Options to Kidnappings Abroad, „China Brief”, 2012, vol.12, issue 10 .

278 Ibidem.

279 Ibidem.

280 Ibidem. 
wraz z dalszym uzależnieniem się tego państwa od dostawców w tych dwóch regionach. Silna pozycja strategiczna Stanów Zjednoczonych na Oceanie Indyjskim i rosnące znaczenie Indii powodują, że Pekin coraz poważniej traktuje rozwój zdolności swojej floty wojennej do prowadzenia działań na tych wodach, rozbudowując m.in. porty w Gwadarze w Pakistanie i terminal kontenerowy w Chittagong w Bangladeszu ${ }^{281}$. W kontekście potencjalnej przyszłej roli Chin na Oceanie Indyjskim często wspomina się o strategicznym znaczeniu dla ChRL Seszeli, które odwiedził w czasie swojej dyplomatycznej podróży po Afryce w lutym 2007 r. prezydent Hu Jintao, a następnie przewodniczący Ogólnochińskiego Zgromadzenia Przedstawicieli Ludowych i członek Stałego Komitetu Biura Politycznego Wu Bangguo w listopadzie $2008 \mathrm{r}$.

Chiny sfinansowały na Seszelach m.in. większość budynków Zgromadzenia Narodowego i Sądu Najwyższego ${ }^{282}$. Położenie Seszeli w niedalekiej odległości od wybrzeży kontynentu afrykańskiego, szlaków handlowych do Azji Wschodniej, vis-à-vis Indii i niedaleko amerykańskiej bazy na Diego Garcia powoduje, że archipelag ten jest idealnym miejscem na potencjalną bazę chińskiej marynarki wojennej ${ }^{283}$. W grudniu 2011 r. Ministerstwo Obrony ChRL potwierdziło, że otrzymało od władz Seszeli ofertę stworzenia na ich terytorium portu zaopatrzeniowego dla floty biorącej udział w operacjach antypirackich w Zatoce Adeńskiej, co media chińskie zrelacjonowały jako zaproszenie do stworzenia bazy marynarki wojennej ${ }^{284}$. Propozycja ta, oczywiście, spotkała się z silną reakcją Indii i Chiny nie przyjęły jeszcze oferty.

Wybrzeża Afryki pełnią coraz ważniejszą rolę w tej grze. W 2000 r. chińska marynarka wojenna po raz pierwszy wysłała swoje okręty z oficjalną wizytą do Tanzanii, RPA i Egiptu ${ }^{285}$. Udział w międzynarodowych działaniach antypirackich w Zatoce Adeńskiej od 2009 r. oznacza, że jej obecność na wodach u wybrzeży Afryki stała się po raz pierwszy w historii zjawiskiem długotrwałym. Choć obecnie flota ChAL-W nie dąży do pozyskania na kontynencie stałych baz, ograniczając swoje działania aprowizacyjne do rozwiązań komercyjnych, na podstawie umów z miejscowymi dostawcami i właścicielami portów, nie jest wykluczone, że wraz z dalszym wzrostem pozycji Chin w regionie utworzenie takich baz będzie brane pod uwagę ${ }^{286}$. Może na to wskazywać m.in. zwiększona częstotliwość

281 D.H. Shinn, Military and Security Relations..., s. 181.

${ }^{282}$ Kamlesh Kumar Agnihotri, Chinese Quest for a Naval Base in The Indian Ocean - Possible Options for China, National Maritime Foundation, http://maritimeindia.org/article/chinese-quest-naval-base-indian-ocean-\%E2\%80\%93-possible-options-china [dostęp 30.01.2013].

283 Ibidem.

${ }_{284}$ P. Simpson, D. Nelson, China Considers Seychelles Military Base Plan, „The Telegraph”, 13.12.2011.

285 D.H. Shinn, Military and Security Relations..., s. 181.

286 S. Kamerling, F.-P. Van Der Putten, An Overseas Naval Presence without Overseas Bases: China's Counter-Piracy Operation in the Gulf of Aden, „Journal of Current Chinese Affairs” 2011, vol. 4 , s. 132. 
zawijania chińskich okrętów z misji antypirackiej do portu w Dżibuti, który doskonale nadaje się na bazę dla marynarki wojennej ChAL-W ${ }^{287}$. Działalność floty chińskiej w Zatoce Adeńskiej stała się w Chinach przedmiotem wielkiej dumy i nasilonej działalności propagandowej. Świadczy ona bowiem o osiągnięciu przez flotę chińską zdolności operowania na strategicznych wodach daleko od kraju i zapewnienia bezpieczeństwa nie tylko własnej żegludze i obywatelom, ale również statkom z innych krajów - w tym z Tajwanu, co ma oczywiście wielkie znaczenie polityczne i symboliczne ${ }^{288}$.

Bardzo istotnym wydarzeniem w kontekście operacji chińskiej floty na wodach przybrzeżnych Afryki było przeprowadzenie zabezpieczenia ewakuacji chińskich obywateli z ogarniętej konfliktem Libii w lutym 2011 r. przez fregatę Xuzhou. Była to pierwsza misja operacyjna chińskiej floty przeprowadzona na wodach Morza Śródziemnego, z przejściem przez Kanał Sueski ${ }^{289}$, a także pierwszy przypadek wykorzystania potencjału militarnego ChRL w odległym regionie świata do ochrony chińskich obywateli ${ }^{290}$. Równocześnie do działań morskich Xuzhou ChAL-W wysłała za zgodą Centralnej Komisji Wojskowej cztery transportowe samoloty Ik-76 z Chartumu do Libii, skąd ewakuowały one do Sudanu 1700 obywateli chińskich ${ }^{291}$. Misja jasno wykazała, że Chiny dysponują już obecnie dużym doświadczeniem i zdolnościami samodzielnych działań wojskowych w regionie Afryki i najprawdopodobniej wzmocniła przekonanie wśród wyższych kręgów dowódczych chińskich sił zbrojnych o korzyściach płynących ze stałej obecności wojskowej w tym regionie ${ }^{292}$.

Chińskie zaangażowanie militarne w Afryce jest pochodną rosnącej siły politycznej i gospodarczej kraju na arenie międzynarodowej. Chcąc zdobyć nowe rynki dla szybko wzrastającego sektora zbrojeniowego i obronnego, ChRL i jej nie zawsze w pełni kontrolowalne przez rząd koncerny zbrojeniowe dostarczają na kontynent duże ilości broni. Brak zgody strony chińskiej na ujawnienie szczegółowych danych dotyczących sprzedaży uzbrojenia w Afryce naraża Pekin na międzynarodową krytykę i podejrzliwość. Chcąc zbudować bezpieczne relacje z państwami Afryki i zapewnić bezpieczeństwo swoim inwestycjom i źródłom cennych surowców ChRL będzie zmuszona do bardziej rozważnego kierowania

287 D. Kostecka, The Chinese Navy's Emerging Support Network in the Indian Ocean, „China Brief" 2010, vol. 10.

288 S. Kamerling, F.-P. Van Der Putten, An Overseas Naval..., s. 138.

289 Misja fregaty Xuzhou zbiegła się w czasie z wizytą autora w ramach niniejszego grantu w Pekinie. W czasie spotkania ze studentami Akademii Dyplomatycznej (Waijiao Xueyuan) stało się jasne, że przyszli chińscy dyplomaci traktują to wydarzenie z niezwykłą dumą w kategoriach historycznego przełomu.

290 G. Collins, A.S. Erickson, Implications of China's Military Evacuation of Citizens from Libya, „China Brief” 2011, vol. 11, issue 4.

291 Ibidem.

292 Ibidem. 
swojego eksportu zbrojeniowego i podjąć większe wysiłki na rzecz ustabilizowania sytuacji militarnej i politycznej w takich państwach kontynentu, jak Kongo, Sudan czy obecnie Mali i Nigeria. Równocześnie będzie ona wzmacniać współpracę $\mathrm{w}$ dziedzinie wojskowości z takimi ważnymi dostawcami ropy i innych surowców, jak Angola, Gwinea Równikowa, Ghana i Nigeria.

\section{Zakończenie}

Zmiany w przywództwie Komunistycznej Partii Chin na XVIII zjeździe w listopadzie 2012 r. nie osłabiły zainteresowania Pekinu kontynentem afrykańskim. Nowy sekretarz generalny KC KPCh wysłał bardzo silny sygnał, że Afryka będzie dla niego istotnym obszarem działań w polityce zagranicznej, włączając trzy kraje kontynentu do planu swojej pierwszej podróży zagranicznej w nowej roli. W marcu 2013 r. Xi Jinping odwiedził trzy kraje kontynentu - Tanzanię, RPA i Demokratyczną Republikę Kongo (bezpośrednio po pierwszym etapie, tj. wizycie w Rosji). W swoim przemówieniu w Dar es-Salam wyraźniej niż jego poprzednik zaznaczył, że stosunki chińsko-afrykańskie nie są pozbawione pewnych problemów, lecz zobowiązał się, iż pod jego przywództwem Chiny dołożą wszelkich starań, by relacje te przynosiły większe korzyści stronie afrykańskiej, poprzez „wspólne opracowanie praktycznych metod rozwiązywania problemów w stosunkach handlowych i gospodarczych" ${ }^{293}$. W tym samym wystąpieniu Xi Jinping metaforycznie określił podniesienie stosunków chińsko-afrykańskich na nowy poziom poprzez dodanie „czterech słów” w czterech sferach. W sferze przyjaźni chińsko-afrykańskiej dodanie słowa „prawdziwa” (chiń. zhen), w sferze wsparcia rozwojowego - słowa „rzeczywiste” (chiń. shi), w sferze wzmacniania przyjaznych relacji - słowa „bliskich” (chiń. qin) oraz w sferze rozwiązywania problemów - słowa „uczciwość” (chiń. cheng) ${ }^{294}$.

Wydaje się zatem, że Chiny pod przywództwem Xi Jinpinga będą kontynuowały zacieśnianie bliskich relacji z państwami Afryki. Może na to wskazywać m.in. podpisanie przez niego z prezydentem Tanzanii umowy o budowie portu morskiego w tym kraju, który, jak uważa część obserwatorów, może stać się w przyszłości wspomnianą wyżej bazą strategiczną dla chińskiej marynarki

293 P. Ford, China's Xi Jinping Visits, Africa Asks: What Are We Getting Out of This?, „The Christian Science Monitor", 26.03.2013, http://www.csmonitor.com/World/Asia-Pacific/2013/0326/AsChina-s-Xi-Jinping-visits-Africa-asks-What-are-we-getting-out-of-this [dostęp 19.05.2013].

294 Guojia Zhuxi Xi Jinping 25 ri zai Tansangniya Nilei'er Huiyi Zhongxin Fabiao tiwei ,, Yongyuan Zuo Kekao Pengyou he Zhencheng Huoban" de Zhongyao Yanjiang [Ważne przemówienie przewodniczącego państwa Xi Jinpinga wygłoszone 25 marca w centrum konferencyjnym im. Nyerere w Tanzanii pt. „Bądźmy zawsze wiarygodnymi przyjaciółmi i odpowiedzialnymi partnerami”], http://news.enorth.com.cn/system/2013/03/26/010784445.shtml [dostęp 19.05.2013]. 
wojennej na Oceanie Indyjskim ${ }^{295}$. Równocześnie jednak rosnące zaangażowanie na kontynencie stawia przed Xi nowe wyzwania, które wymuszą dalsze doskonalenie narzędzi polityki wobec kontynentu i budowę lepszego wizerunku chińskiej obecności w Afryce. Odziedziczone przez Xi narzędzia jak dotąd skutecznie zapewniały Chinom korzyści płynące ze stosunków z Czarnym Lądem. Jednak ambitnie zarysowane przez przywódcę Chin cele, określane w nowym dyskursie jako „chińskie marzenie” (Zhongguo meng), mające przynieść temu państwu m.in. jeszcze większą rolę w polityce międzynarodowej, będą wymagały dopracowania zastałych rozwiązań i stworzenia zupełnie nowych. Czas pokaże, jak zmienią się metody postępowania ChRL wobec afrykańskich partnerów i czy deklarowane przez Xi zacieśnienie relacji będzie postępowało w duchu „,czterech słów” z przemówienia w Dar es-Salam.

${ }_{295}$ Patrz np. China Media: Xi Jinping in Africa, BBC, http://www.bbc.co.uk/news/world-asiachina-21921045 [dostęp 18.05.2013]. 